\title{
Do We Need a New Florence Charter? The Importance of Authenticity for the Maintenance of Historic Gardens and Other Historic Greenery Layouts in the Context of Source Research (Past) and Taking into Account the Implementation of the Sustainable Development Idea (Future)
}

\author{
Marzanna Jagiełło (D)
}

check for

updates

Citation: Jagiełło, M. Do We Need a New Florence Charter? The Importance of Authenticity for the Maintenance of Historic Gardens and Other Historic Greenery Layouts in the Context of Source Research (Past) and Taking into Account the Implementation of the Sustainable Development Idea (Future). Sustainability 2021, 13, 4900. https://doi.org/10.3390/su13094900

Academic Editor: Jan K. Kazak

Received: 28 February 2021

Accepted: 15 April 2021

Published: 27 April 2021

Publisher's Note: MDPI stays neutral with regard to jurisdictional claims in published maps and institutional affiliations.

Copyright: (C) 2021 by the author. Licensee MDPI, Basel, Switzerland. This article is an open access article distributed under the terms and conditions of the Creative Commons Attribution (CC BY) license (https:/ / creativecommons.org/licenses/by/ $4.0 /)$.
Department of Architecture Conservation and Restoration of Cultural Landscape, Faculty of Architecture Wrocław, University of Science and Technology, 50-317 Wrocław, Poland; marzanna.jagiello@pwr.edu.pl

\begin{abstract}
This year, 40 years have passed since the adoption of the basic document for the protection of historic gardens, i.e., the Florence Charter. During this time, its recommendations have been verified by both conservation and researchers' actions, who in various environments discussed its meaning as well as its essential shortcomings. Some of the provisions of the Charter were criticized in the context of the effects of their use, especially those relating to the issue of historic gardens fundamental protection, namely to authenticity in its various scopes with particular emphasis on the use of source research which raises many reservations for conservation actions. Moreover, their excessively superficial interpretation, which was demonstrated by the example of the most popular plant used in regular gardens, namely boxwood. This article presents and analyzes the most important theses of these discussions and the main axes of the dispute, dividing them into two parts, i.e., the first relating to authenticity and the other to the use of sources. On this basis, it was necessary to extend these considerations to all kinds of historic greenery. Attention was also paid to the meaning and scope of authenticity which changed along with the expansion of the semantic field in relation to heritage. Furthermore, the fact that since the adoption of the Florence Charter, some of the aspects of authenticity indicated in the article have been included in other documents developed under the auspices of ICOMOS, but usually relating to the heritage as a whole, sometimes considered regionally. Appendices contain the most important doctrinal documents referring separately to authenticity, meaning, as well as types and the scope of the usage of sources. This article presents new contexts in which authenticity connected with climate change and the postulates of the development doctrine should be considered. Additionally, the article indicates the need to extend the conditions in which to start considering the historical greenery areas, which should be treated as an element of green infrastructure. The article also points to the use of new techniques and tools in research on authenticity. The summary indicated the necessity to continue the discussion on aspects of authenticity in relation to historic greenery layouts. Taking into account all the above aspects and at the same time meeting the ICOMOS “Journeys for Authenticity" initiative, As part of the conclusions from the analyzes carried out in the article, a model of procedure was proposed. It aims to bring us closer to the preparation of a new document recommending the protection of historic greenery, addressing both critical comments about the present Florence Charta, as well as new challenges and opportunities. This model is shown by means of a diagram. Part of it is a set of themes around which around which the debate on the new Florence Charter could be launched. They were assigned to four panels, i.e., I. Historic greenery as an element of heritage: II. Authenticity of historic greenery complexes in research and conservation strategies; III. Authenticity of historic greenery complexes and sustainable development; IV. New techniques and tools in research on the authenticity of historic greenery layouts.
\end{abstract}


Keywords: Florence Charter; world heritage convention; cultural heritage; historic gardens; authenticity; criteria; documentation; preservation; restoration; landscape architecture; green infrastructure of the city; sustainable development; interdisciplinary approaches

\section{Introduction}

The subject of the analyses undertaken in this article covers historic gardens, defined by the fundamental and updated official document concerning their protection, which is the Florence Charter, as "an architectural and horticultural composition of interest to the public from the historical or artistic point of view [ ... ] must be preserved in accordance with the spirit of the Venice Charter" [1] (Art. 3), to which also other forms of historic greenery were added such as cemeteries, urban green areas (promenades, parks, boulevards and avenues) and public green spaces characterized in the ICOMOS-IFLA Document on historic urban parks as "an essential and inalienable part of traditions and plans of many towns and settlements" [2] (preamble).

It should be recalled here what was meant when writing about "architectural and horticultural composition". Namely, it is about the layout, plant complexes, structural and decorative elements as well as water with the sky reflected in it [1] (Art. 4).

Most of the preserved gardens and green areas under protection are now much more than 100 years old. Some of their elements show significant durability, however plants, except for some species of trees, do not live that long. The Florence Charter recommends their cyclical replacement, which, however, raises a lot of controversy among researchers, even if care is taken (in historical terms) in the selection of plant species. Questions also appear when it comes to restoration combined with partial restitution of green complexes (full reconstruction as an action the result of which "could not be considered a historic garden" [1] (Art. 17) will in principle not constitute the subject of these considerations). On the one hand, criticism is given to the overly literal reading of the Florence Charter's records regarding the use of sources, as well as incomplete or even incorrect interpretation of source materials. On the other hand, there are methodological errors which seem to be missing a deeper interdisciplinary reflection on various aspects of authenticity in relation to historic gardens. All this resulted in the fact that in many countries (although not in all of them) recommendations for the protection of historic gardens contained in the Florence Charter, as well as in other documents of this rank, are contested or even ignored.

Relatively new aspects have also contributed to this, in the context of which historic green areas are considered, also in the context of authenticity, namely the management of historic gardens, and more broadly of historic green areas, which will take into account sustainable development programs, especially in the ecological context, i.e., maintaining biodiversity and managing ecosystems [3].

It all seems to raise a justifiable question about the need to discuss a new document on historic greenery layouts, taking into account both the current experience as well as new challenges.

\section{Materials and Methods}

This article is part of the series of research carried out earlier by the author (together with W. Brzezowski) on the problem of authenticity in historic gardens, which was analyzed in various scopes referring to the following: reconstruction [4], vegetation [5] and the importance of exotic plants [6]. These analyses were connected with the research on Silesian gardens (today the region of Poland, previously belonging successively to Poland, Bohemian Kingdom, the Habsburg Monarchy, Prussia and then to Germany until 1945) from the Middle Ages to the Baroque period, the results of which were included in a two-volume study [7,8]. At that time, significant discrepancies in the interpretations of various aspects, including source materials connected with historic gardens were noticed by different authors, the consequence of which were inconsistent research results, and then 
controversial in terms of authenticity conservation activities. The consistent expansion of the observation field allowed the author to go beyond the borders of Silesia and after a deeper analysis, to make an attempt at formulating comments of a more general character. They were made on the basis of two objectives which were identified for the purposes of this article in the following way:

1. firstly, the discussion of authenticity in relation to historic gardens and other forms of historic greenery were analyzed, taking into account various scopes and aspects in which this issue were addressed; in this context, both official documents (Appendix A) as well as contemporary theories and opinions of researchers were taken into consideration, including an interdisciplinary approach to the issue of authenticity; at the same time, attention was paid to the ecological aspects of protection of historic green complexes in the context of sustainable development;

2. secondly, types of sources and methods of analyzing them and then using the results obtained in this way in research on historic gardens in the context of their authenticity, and then in activities of a conservation character; at the same time, attention was drawn to the risks for authenticity resulting from the lack of a critical approach to the content of some sources; recommendations on the use of source materials contained in official documents were also compiled (Appendix B).

The basic methods, which were adopted in this article, are derived from the methodological canon adopted in the humanities, i.e., the queries of written sources, including old treatises on garden art, as well as historical descriptions and iconographic materials with particular emphasis on old engravings, paintings, designs, plans and maps. This made it possible to draw attention to the dangers resulting from their insufficiently critical use in many cases as well as to formulate suggestions of issues which could constitute the basis for further discussions on the character of the new document devoted to the historic greenery layouts.

In the theoretical considerations on authenticity, the documents relating to historic buildings (including gardens) were analyzed, starting with the Venice Charter [9], through the already mentioned basic document regulating protection of historic greenery, the Florence Charter (1981) which complements the Venice Charter with points regarding historic gardens, thanks to which their protection received a lot of support for the first time, allowing the emergence of a specialized discipline, after the Nara Document on Authenticity [10] in which attention was paid to cultural conditions in assessing the value and authenticity of monuments. Reference was also made to the 2017 ICOMOS-IFLA Document, in which, for the first time, official recommendations highlighted the protection of public green areas [2]. More general regulations were also applied, i.e., the London Charter which codified the principles of computer methods for visualizing cultural heritage [11] as well as the Xi'an Declaration on the Conservation of the Setting of Heritage Structures, Sites and Areas [12]. The latter emphasizes a multidisciplinary approach in research and documentation of the environment and the importance of various sources of information for full "understanding" and "interpretation" of the value and importance of the surroundings of buildings, sites, and areas which constitute heritage. Local regulations were also studied, especially those with a broader international range of influence, such as the Burra Charter [13] and the Declaration of San Antonio which was organized by ICOMOS and constituted a summary of InterAmerican Symposium on Authenticity in the Conservation and Management of the Cultural Heritage to discuss the meaning of authenticity in preservation in the Americas [14].

The above-mentioned documents were confronted with the previous conservation practice and related problems as well as with views on the issue of authenticity in the context of gardens [15-31]. In this context, the discussion on the Florence Charter in recent years in the environment of German and Swiss researchers turned out to be very interesting [19,31,32].

The publications devoted to historic green areas and their management in the context of sustainable development were also applied, including, among other things, those pub- 
lished in the last month of 2020 on the pages of "Sustainability" in Special Issue "Challenges for Historic Gardens Sustainability between Restoration and Management" [33,34]. At the same time, attention was paid to the increasing number of voices raising the issue of the importance of historic gardens in the biodiversity protection strategy [35] as well as to the dangers to maintaining authenticity of historic greenery layouts, especially those located in cities and connected with climate change and its consequences [36]. In this context, attention is drawn to the more and more frequent treatment of urban parks and gardens as green infrastructure of cities [33].

New possibilities of researching historic greenery layouts were also indicated, which made it possible to verify some source messages. They are enabled by modern technologies, including laser scanning (TLS and LIDAR), which are one of the most modern techniques of obtaining data for the numerical model of the area (including the garden). Geophysical methods used in archaeological research are also very useful, such as: Electromagnetic conductivity (EM) and ground-penetraiting radar (GPR) [37,38]; see Figure 1. Orthophoto is also used for research purposes; see Figure 2. The use of these modern methods has been sanctioned in the London Charter (2009), which also defined the "Principles for computer methods of visualizing cultural heritage". We can read in it, inter alia, that "In order to ensure the intellectual integrity of computer-based visualization methods and outcomes, relevant research sources should be identified and evaluated in a structured and documented way" [11] (Principle 3). This makes it possible to apply computer visualizations to present historic greenery layouts in situations when it is not possible to reconstruct their original state in terms of authenticity.

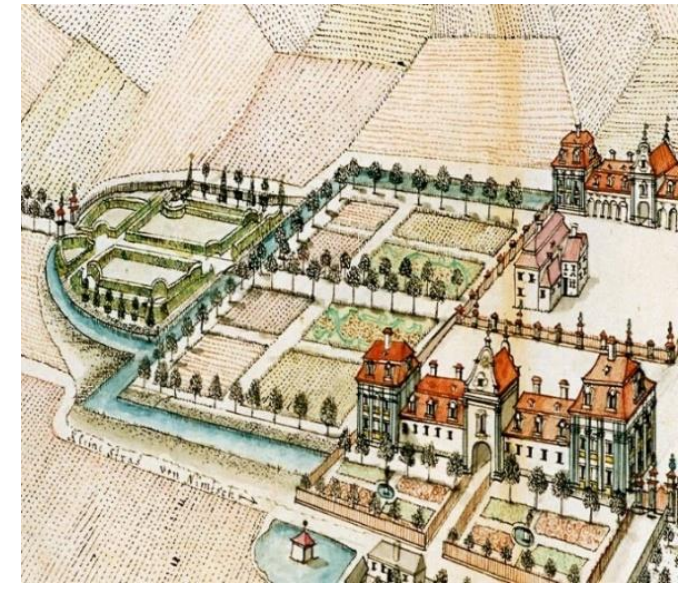

(a)

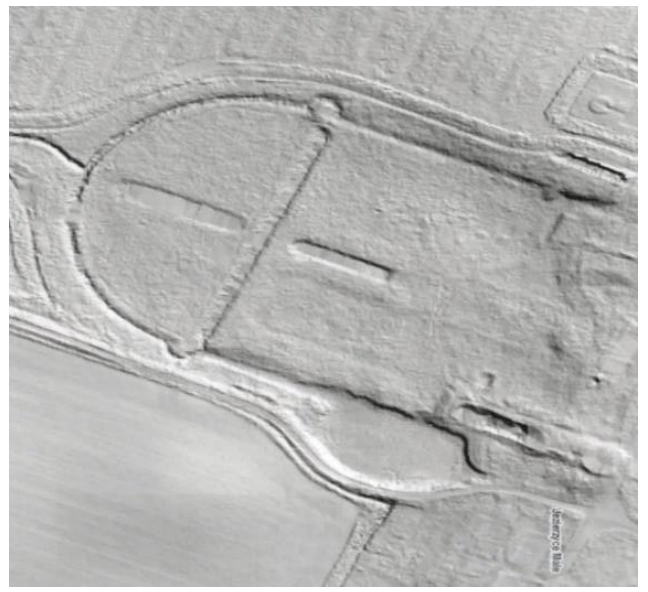

(b)

Figure 1. Establishment of a manor and garden in Jezierzyce Małe (Silesia, Poland): (a) F.B. Werner drawing from around the middle of 18th century. In collection of University Library in Wrocław II, 497; and (b) model of the terrain in the LIDAR system showing the actual course of the canal surrounding the garden in Jezierzyce other than in Werner's drawing; from (public domain) http: / / www.geoportal.gov.pl/ (accessed on 8 September 2015). 


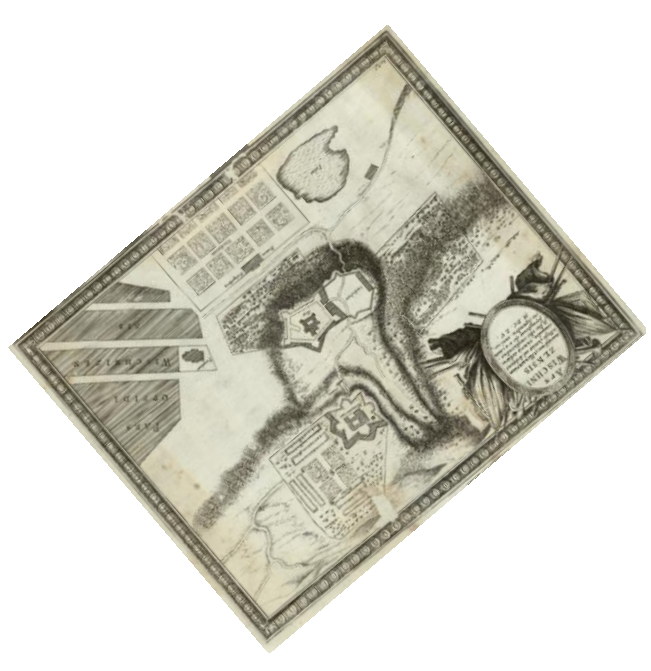

(a)

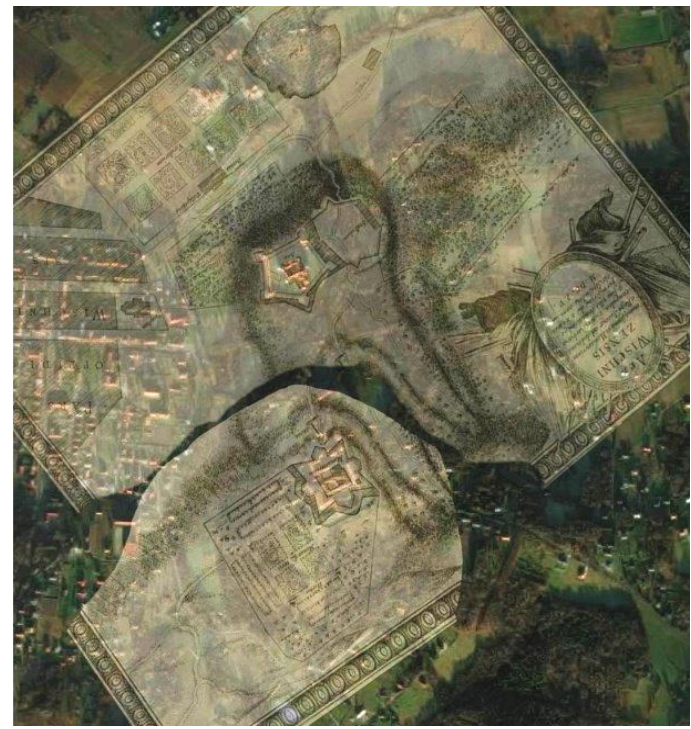

(b)

Figure 2. Fortress in Wiśnicz (Poland): (a) on the engraving of Dahlberg, 1655. Author's collection. (b) on an orthophotomap with a "cut" Dahlberg plan, comp. M. Myczkowsk-Szałankiewicz, 2017.

\section{Results}

\subsection{The Issue of Authenticity}

For the first time in the official document, in the context of cultural heritage protection, the term "authenticity" appeared in the Venice Charter in relation to restoration and with the following recommendation "respect for original material and authentic documents" [9] (Art. 9). Just a bit more extensive was the reference to authenticity in the Florence Chapter, where we read that "The authenticity of a historic garden depends as much on the design and scale of its various parts as on its decorative features and on the choice of plant or inorganic materials adopted for each of its parts " [1] (Art. 9). Only in the Nara Document on Authenticity records, was authenticity recognized as the most important quality factor. For it says: "Our ability to understand these values depends, in part, on the degree to which information sources about these values may be understood as credible or truthful. Knowledge and understanding of these sources of information, in relation to original and subsequent characteristics of the cultural heritage, and their meaning, is a requisite basis for assessing all aspects of authenticity" [10] (Art. 9). At the same time, the criteria for assessing authenticity were relativized by saying: "It is thus not possible to base judgements of values and authenticity within fixed criteria" [10] (Art. 9). This was pointed out by David Lowenthal who noticed that "Authenticity is never absolute in practice, always relative" [28] (p. 4).

The role, meaning and aspects of authenticity defined in the Nara Document were commented on and developed in the Declaration of San Antonio. We refer to it here because of the findings contained therein which extend and at the same time organize the issue of authenticity, relating to "1. Authenticity and identity (The authenticity of our cultural heritage is directly related to our cultural identity); 2. Authenticity and history (An understanding of the history and significance of a site over time are crucial elements in the identification of its authenticity); 3. Authenticity and materials (The material fabric of a cultural site can be a principal component of its authenticity)". This Declaration also drew attention to other aspects of authenticity which were absent in earlier documents, namely "authenticity and social value", "authenticity in dynamic and static sites", "authenticity and stewardship" and "authenticity and economics" [24], referring them to all categories of objects and places which make up the heritage. This document also includes recommendations suggesting "That further consideration be given to the proofs of authenticity so that indicators may be identified for such a determination in a 
way that all significant values in the site may be set forth. The following are some examples of indicators: Reflection of the true value. That is, whether the resource remains in the condition of its creation and reflects all its significant history. Integrity. That is, whether the site is fragmented; how much is missing, and what are the recent additions. Context. That is, whether the context and/or the environment correspond to the original or other periods of significance; and whether they enhance or diminish the significance. Identity. That is, whether the local population identify themselves with the site, and whose identity the site reflects. Use and function. That is, the traditional patterns of use that have characterized the site" [8]. These recommendations, apart from the general ones mentioned above, refer to three groups of objects and places: 1 . architecture and urbanism; 2 . archeological sites group and 3. cultural landscape group. Although the last group is so capacious that some actions related to the landscape can also be related to the historic greenery layouts, it is noteworthy that this element of heritage is not mentioned directly (American specificity).

It should be noticed here that the authenticity of the broadly understood heritage was also discussed outside official documents, also in the context of other values which monuments carry with them, namely historical, emotional, cultural, aesthetic, artistic, the value of antiquity, identity, quotation, sociological and psychological and finally ecological values, to which various researchers of the issue added authenticity and tradition of a place-genius loci, including authenticity of a specific place-situs [39]. Let us also recall that the Declaration on the Preservation of the Spirit of Place was adopted in Québec by the General Assembly of ICOMOS only in 2008. It drew attention to the protection of intangible elements of cultural heritage.

Recognizing the importance of the issue of authenticity for the protection of cultural heritage, in 2010, on the initiative of ICOMOS, all international and local documents (of various ranks) as well as the findings of conferences and scientific symposia, in which the authenticity criterion was taken into account, were collected and put together. The whole comparison was divided into two parts (theoretical aspects and practical aspects) and included 282 titles, although only nine (including some which are connected with the Nara Document) were directly related to gardens [40]. This is an important observation because in the case of all other monuments and objects, in the unanimous opinion of researchers, theorists and in the provisions included in legal acts, "only an authentic monument is a carrier of historic and scientific values [ ... ]. Therefore, preserving the full value of a monument is possible only when we record and conserve its original matter" [41]. In relation to historic gardens, we are forced to particularly modify the authenticity defined in this way. For in this special case, we are dealing (in its natural part because the remaining elements are essentially subject to the provisions of the Venice Charter) with the matter which, while alive, is subject to natural processes involving the life of individual plants. This became the basis for thinking about the garden as a dynamic composition, in which the durability of the whole depends on the durability of its components, mainly plant components, and the average lifetime of one generation of plants was estimated for about 100 years. In this case-in accordance with the recommendation of the Florence Charteran extension of the spatial form in order to maintain a harmonious spatial continuity of all plant forms should take place by means of "prompt replacements when required and a long-term program of periodic renewal clear felling and replanting with mature specimens" [Florence Charter, Art. 11]. Such a procedure was accepted and has been practiced in many countries to this day, also in Poland [17] (pp. 16-17).

Let us make it clear that the recommendation for periodic replacement of plant forms was supplemented in the Florence Charter with the recommendation that the species selection of plants used in this process should be based on "selection with regard for established and recognized practice in each botanical and horticultural region, and with the aim to determine the species initially grown and to preserve them" [1].

Directly to authenticity, the Florence Charter refers-as already mentioned - to this very generally, thus opening the door to many far-reaching activities which will be pre- 
sented later in this article. Its records mean that authenticity in the context of historical gardens should be considered in two aspects:

1. "design and scale of its various parts as on its decorative features"

2. "plant or inorganic materials adopted for each of its parts" [1] (Art. 9.)

The wording in the Charter on determining the appropriate vegetation "with the aim to determine the species initially grown and to preserve them" requires some commentary here [1] Art. 12. The question is how to relate it to cases so stylistically complex and at the same time rich in historical, artistic and social meanings and roles, as the Villa d'Este gardens in Tivoli, which was inscribed on the World Heritage List in 2001; see Figure 3.

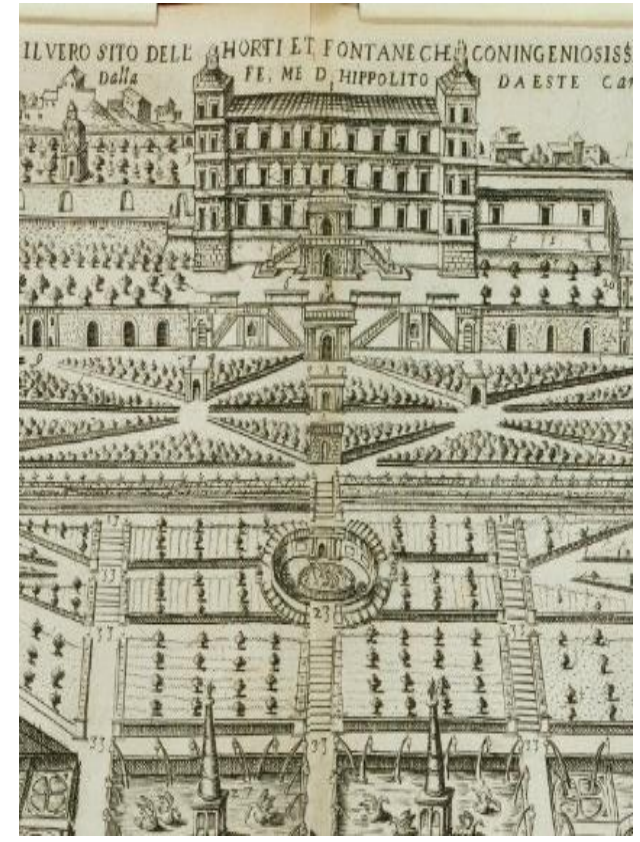

(a)

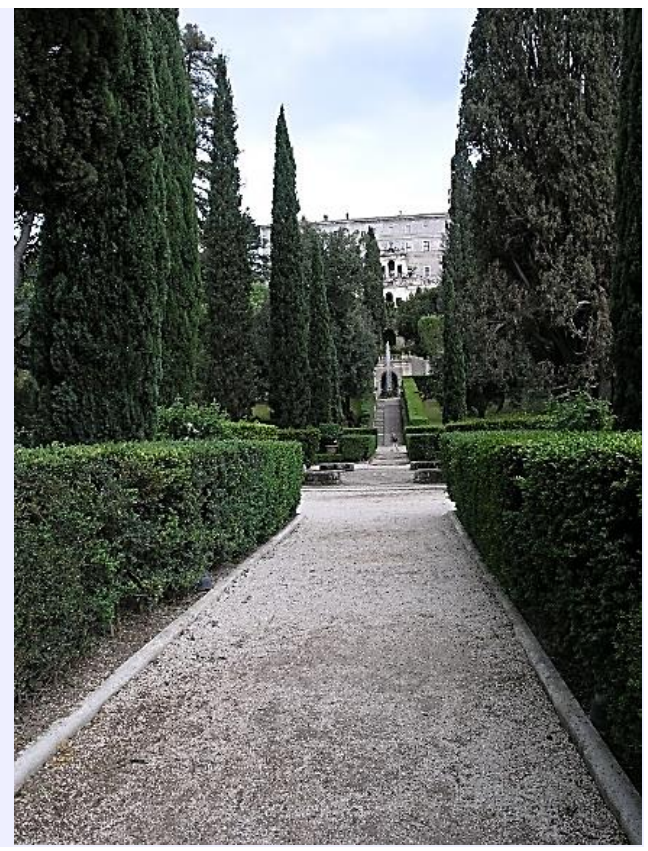

(b)

Figure 3. The main compositional axis of the Villa d'Este garden in Tivoli: (a) fragment from an etching by G.A. Brambilla; from (Public domain); https:/ / .pinimg.com/originals/1d/9d/fd/1d 9dfd4177025bef3e43763884f041f6.jpg?epik=dj0yJnU9WlhPdzFPUII4MGVMSjVrUENWdndpUD hKQT1ZU3c2WXEmcD0wJm49UVZIbjFlbjBmaGREQXIVSF9GLVdCdyZ0PUFBQUFBR0FWWnp3 (accessed on 8 December 2020). (b) in contemporary photography. Photo W. Brzezowski, 2014.

We will come back to Tivoli Gardens, however, at this stage, we will turn to situations which are clearer, that is, to gardens that maintained their stylistic unity, or where such unity is sought through partially regenerative activities. In such cases, a botanical aspect considered in the context of authenticity deserves special attention. We noticed that failure to exercise due diligence in maintaining authenticity of gardens, understood as the initial nature appropriate for various historic periods, too often leads to the introduction of plants which had not been originally cultivated there, e.g., boxwood in many gardens with a medieval and Renaissance origin and located to the north of the Alps, and sometimes even in the historic past of many unknown gardens, such as plantain lilies (in Europe only since 1830) and hydrangeas (the first in Kew Gardens in 1789), which we can find in some old cloisters, for example in the territory of today's France and Belgium [42] as well as Poland [7] (pp. 47, 77-80).

Many researchers also criticized the point exchange, which was recommended by the Florence Charter and used in such cases, which aimed at restoring gardens to their original "youthful" condition. From the beginning of the 1990s, they began to treat this type of plant exchange as a reconstructive action consisting in the removal of evidence important for the diagnosis of the history of the garden. As already mentioned, an in- 
teresting discussion on this subject took place in the environment of German and Swiss researchers. The Swiss art historians, Brigitt Sigel encouraged to change the approach to such practices, which were recommended by the Florence Charter, i.e., "It is the duty of a conservator-restorer to preserve material traces of history, not to recreate a textbook model". In her opinion, it is impossible to "destroy the authentic traces of history" and then recreate them because "history cannot be recreated" [16] (p. 274). This topic was taken up by German landscape architect and researcher Erika Schmidt who paid attention to the importance of plants as historic sources [28] (p. 270) and postulated the extension of life of not only permanent elements, but also plants by means of gardening procedures which respected the limitation of intervention. Ingo Kowalik, an ecologist, went even more broadly in similar considerations, i.e., he connected protection of garden monuments with nature conservation, also in terms of ecology [18]. This debate can be considered as a summary expressed in 2006 in the publication published under the meaningful title "Der Garten-ein Ort des Wandels." [19], in which, after Italian conservator of gardens Lionella Scazossi, the authors used the term "opera aperta", treating the garden as an open work, constantly and dynamically changing, which clearly indicated the need to "preserve the traces of a complex past without interrupting this process". At the same time, it was acknowledged that it was "possible if the historical analysis did not serve as a starting point for reconstruction" [19]. Such an attitude brings us significantly closer to taking into account the goals set in the documents on sustainable landscape management as regards gardens. They were included in the European Landscape Convention (Florence Convention), where we read, among other things, "Landscape management" means action, from a perspective of sustainable development, to ensure the regular upkeep of a landscape, so as to guide and harmonize changes which are brought about by social, economic and environmental processes" [43] (Art. 1.e). Attention is drawn to the fact that, so far, no other doctrinal documents concerning the protection of heritage in the context of historic greenery have addressed this issue. Perhaps the results of research on various ecosystems in the context of ecology and biodiversity should be used for this purpose.

A specific voice in the above-mentioned debate could be the view which was formulated many years ago (1961) by Polish art historian and conservator-restorer Józef Dutkiewicz who used the "myth about overcoming death" in relation to monuments. In the garden context, it can be read as "eternal life" thanks to the rebirth of nature resulting from the vegetative process and from the repeated cycles of plant reproduction, the way of their genetic self-copying and in this biological sense, preserving authenticity and even "immortality" [44] (p. 6).

The discussion about treating historic gardens as an "opera aperta" was undertaken by Austrian historian of gardens Geza Hajos, who contrasted the garden defined as "a place of changes" [19] with "a historic garden-as a place of remembrance" because-as he particularly emphasized - "the historical garden is not a work of nature but a work of man" [22] (p. 23). Hajos also formulated ten "theses for discussion" which were connected with the protection of garden heritage. In terms of authenticity, he referred to the Nara Document, stating at the same time that some reconstruction activities (such as restoring the course of paths, flowering specific to a given period) should not arouse any controversies. He also warned that the polarization of two extreme methods, both long-term conservation (up to the disappearance of some plant forms and, consequently, the destruction of the garden structure) and the "artistic continuation" standing on the other extreme, is equally dangerous for historic gardens [22] (p. 220).

With a similar vein joined this exchange of views Stefan Rhoter, retired director of Bayerischen Verwaltung der staatlichen Schlösser, Gärten und Seen (The Bavarian Administration of State-Owned Palaces, Gardens and Lakes). By analyzing both of the above positions, he came to the conclusion that it was impossible to establish uniform and universal rules. He advises on an individual approach which should be adjusted to the circumstances. He recommends the use of all methods, even the reconstruction of missing elements, provided that their "original shape has been documented and the 
existence of which is essential for understanding the monument, which should be preceded by thorough research" [25] (p. 63). Rhotert also calls for "honest information to visitors" about any reconstructions and also draws attention to the costs of not only restoration and reconstruction activities, but also the subsequent maintenance of gardens, in the case of private layouts which often "overwhelm financially". He also writes about social aesthetic pressure, especially in the context of tourist facilities which are available for tourists, emphasizing that these "less restored, although not less historically valuable complexes often have a dark existence" [25] (p. 64).

Dorota Sikora, a Polish landscape architect and author of publications devoted to the specific nature of conservation actions in regular gardens, also referred to the issue of plant replacement [20]. She justified her decisions regarding the reconstruction of Branicki Garden in Białystok (see Figure 4) with source texts, referring to the recommendations contained in the treatise Dezalier d'Argenvillee [45], which recommended that for the formation of avenue trees and divine plantings, specimens up to nine meters high, so that they would be adapted to the rest of the garden composition. Consequently, it was supposed to mean periodic replacement of trees, although it is not known whether it was actually carried out in the past. Sikora also referred to some examples of contemporary activities in historic gardens based on the replacement of tree stands (Schwetzingen, Herrenhausen, Hampton Court, and also Versailles) [20] (pp. 32, 47).

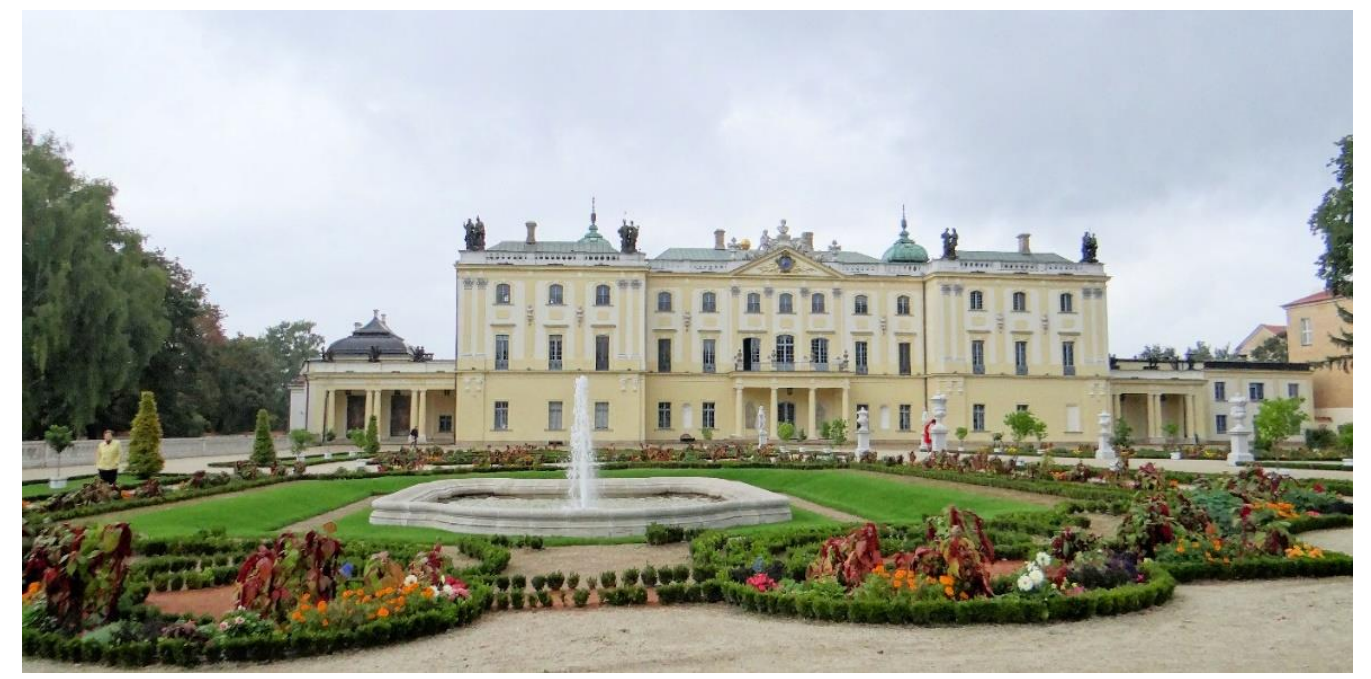

Figure 4. The Branicki garden in Białystok, reconstructed on the basis of source materials and research. Fot. J. Dyr., 2013; from (Public domain) https: / / upload.wikimedia.org/wikipedia/commons/thumb /c/c1/150913Garden_of_the_Branicki_Palace_in_Bia\%C5\%82ystok-02.jpg (public domain) (accessed on 8 January 2021).

Let us return, however, to the consideration of authenticity. What else, in terms of the authenticity of historic gardens, does the Florence Charter not refer to? It does not take into account, for example, the loss of this value in cases connected with the movement-even justified for the purposes of protection - of monuments constituting the "equipment" of gardens, which in general is made possible-under certain conditions-by the provisions of the Venice Charter [9], (Art. 7, 8). The Polish example is provided by, for example, a complex of baroque sculptures currently decorating the upper and lower terrace of the former royal Wilanów Palace in Warsaw, coming from Brzezinka near Wrocław (until 1945, the German Briese); see Figure 5. A change in the original composition consisting of 22 statues in Wilanów led to a departure from the original, we would say "authentic" symbolic and content program, which probably was not in line with the iconographic message which was conveyed by the sculptures originally standing in Wilanów Garden and were then stolen by the Russian Army in 1804 [8] (pp. 346-352). 


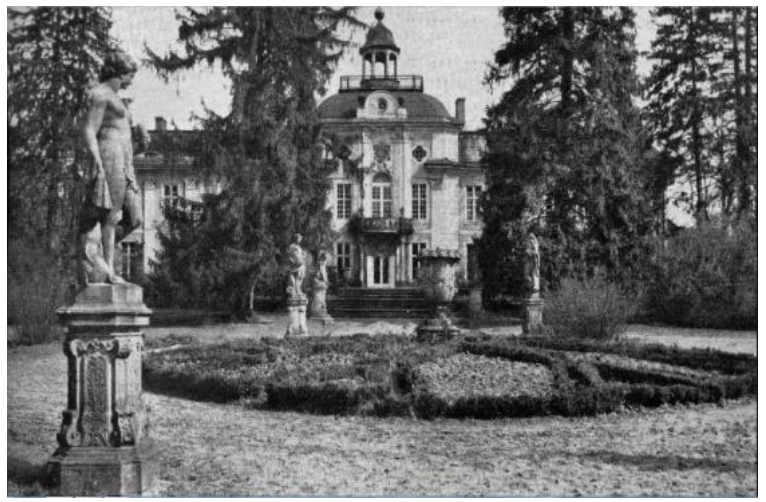

(a)

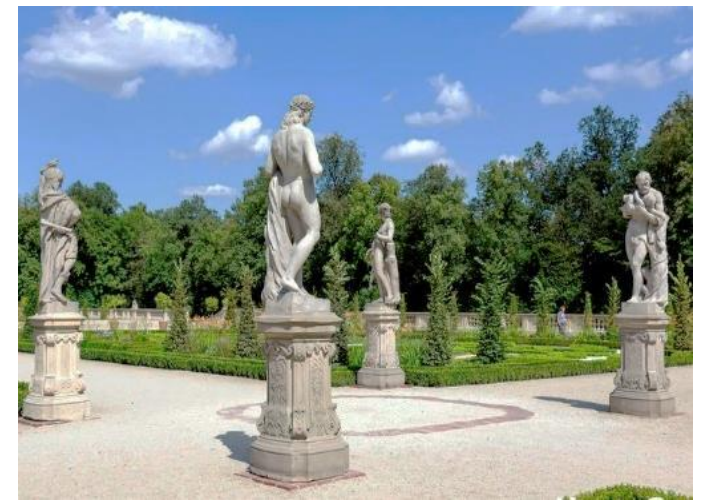

(b)

Figure 5. Baroque sculptures: (a) in the garden by the palace in Brzezinka in Silesia (Poland). Photo unknown author, circa 1930; from (Public domain) https: / fotoposka.eu/Brzezinka/b22278,Palac_Kospothow.html?f=1276070-foto (accessed on 8 January 2021). (b) the same sculptures after they were moved to the garden of the residence in Wilanów (Warsaw, Poland). Photo M. Jagiełło, 2013.

At this point, we should pay attention to the fact that the symbolic and content-related significance played this time a key role in the case of a group of gardens known as Masonic (for example, Parc Monceau-France, Louisenlund-Germany and Nieborów-Poland). The awareness of this fact and its consequences for the composition of such layouts, in particular the form and role which were originally given to its individual elements and their mutual relations, should be of fundamental importance when seeking solutions to protect both their authentic substance and the original message $[46,47]$.

The Florence Charter does not comment exhaustively on another important aspect of authenticity, namely the "garden existence" which was formulated by Dmitry Likhachov [48] (p. 78) and understood as the original purpose of the garden. This very often determined, for example, the width of the avenue, the height of hedges, the length of the canals, the extent of water mirrors and the area of meadows. It also referred to the use of certain elements of garden staffage some time ago, for example in the form of shepherds surrounded by a herd of cows or sheep, which was to transport observers to idyllic Arcadia. Today their reconstruction would not meet-as one can assume-with the proper reception in the context of authenticity.

As above-mentioned in this article, Erika Schmidt also drew attention to the aspect of authenticity connected with the "garden existence", referring it to the Florence Charter, where it was written that it was essentially the "place of enjoyment suited to meditation or repose" and was associated with various problems which result from the modern use of many historic gardens far beyond those defined in the Charter [29] (p. 85).

It is also worth adding that the quoted "garden existence" is also connected with the issue of authenticity relating to former users, who, being equipped with a kind of thesaurus constituting an attribute of every "well-mannered" and sometimes even well-educated person, easily read a symbolic code of the garden (we must add that it was different in subsequent epochs). It is usually unavailable to a modern recipient. However, it should not be overlooked in research on historic gardens.

When looking at fountains, cascades and other water arts gushing out in many iconographic representations, we should also think with reserve in assessing authenticity in the context of "garden existence". In most of the gardens (except for the Italian parts using natural springs and favorable topography) they were activated only for a moment when the owner was watching them. This was not always because of saving water (in the modern sense), but rather because of the difficulties which had to be overcome in order to deliver it in the days before the steam engine and electricity appeared, often using complicated devices for this purpose, such as the famous machine from Marly (see Figure 6), which worked in Versailles from 1684 or other devices and systems for obtaining and effective 
use of water, designs of which were included in the pages of many old treatises of works, among others [49-52]. Today, water, which is supplied by waterworks and the inflow of which we will probably have to limit again, gushes from them.

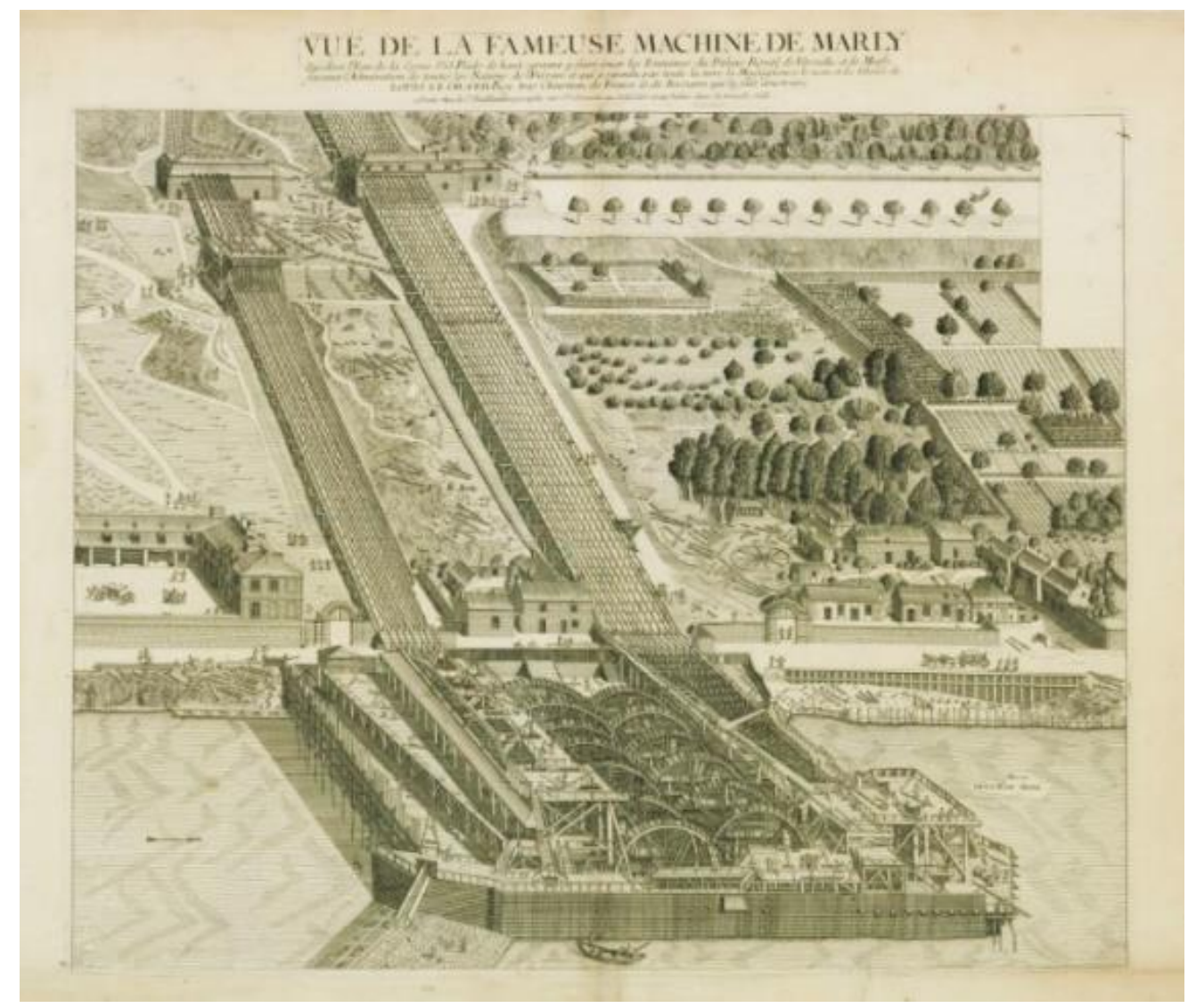

Figure 6. A machine from Marly that once fed the gardens of Versailles. A drawing from the beginning of the 18th century. Collections gallica.bnf.fr/Bibliothèque nationale de France; from (Public domain) https:/ / gallica.bnf.fr/ark:/12148/btv1b6945480x/f1.item.r=machine\%20marly.z oom (accessed on 8 January 2021).

The Florence Charter does not connect stylistic analyses with aesthetic criteria appropriate for the particular epochs, which are illegible or out of date today. This document was limited to a general statement that the garden is "a testimony to a culture, a style, an age, and often to the originality of a creative artist" [1] (Art. 5). As such, it happens that these aesthetic criteria acquired new different meanings like, for example, sublimity-once referring to the sphere of impressions and dynamically changing emotional experiences as well as picturesqueness-defined in the past as a sudden changeability, austerity and uniqueness, and nowadays it characterizes attractiveness. Let us recall here that picturesqueness created the picturesque style, in which the main role was played by the painting experience (replacing the gardening, architectural and engineering) of a garden designer, his knowledge of compositions, the ability to use chiaroscuro and color and to seek harmony [8] (p. 77). Perhaps in the case of this type of gardens, they should be included in the competences of conservators or people cooperating with them.

In the Florence Charter there is also no mention about the importance of cultivating old agrotechnical techniques and methods, which to a large extent determined the shape and character of gardens. A record of such a value of them did not appear until the Nara Document. This aspect of authenticity was noticed during, inter alia, the reconstruction of the famous Cornish Lost Gardens of Heligan, not only in terms of the layout and fidelity to the plant species once cultivated here, or the original irrigation system, but also 
in a meticulous approach to the old methods of their cultivation, which were recreated with reverence (e.g., pineapples) [53]. When thinking about techniques, we should not forget about old engineering and technical possibilities of setting up gardens. Gardens, as engineering undertakings in historical terms, are still waiting for thorough examination, also in the context of authenticity [54].

Another issue which raises controversy is the Florence Charter's record which recommends an analysis of broadly understood "documentation" and the possibility of obtaining knowledge on this basis, which could become the foundation for the restitution of certain parts of gardens "on the basis of the traces that survive or of unimpeachable documentary evidence" [1] (Art. 16). The rationale for such actions would be, for example, the reconstruction of the historical relationship between the garden and buildings so that it would become clear again ("reconstruction work might be undertaken more particularly on the parts of the garden nearest to the building it contains in order to bring out their significance in the design") [1] (Art. 16). Erika Schmidt raised an objection to this provision, appealing for "respect for the internal value of the garden and its individual historical development. It often took place independently of the development of the complex" [29] (p. 85).

We are able to quote numerous examples of actions taken in accordance with the recommendations of Florence Charter in order to reconstruct stylistic relationships between the garden and the building in recent years also in Poland in, among other things, Branicki Garden in Białystok (2009-2011), in the case of bishop's gardens in Wrocław (2002) and in Wilanów, where in the years 2010-2012 the immediate surroundings of the palace were reconstructed, labeling this action with the term "conservation creation", translated as "a creative continuation of the spirit of the composition" [55]. The restoration of the gardens on the basis of the "dialogue with historic sources" also took place at the gothic wing of the Royal Castle in Warsaw. As it seems, unfortunately, there is environmental acceptance for this type of actions, considered permissible because they are in accordance with recommendations of the Florence Charter. It was also included in the basic coursebook on the protection and conservation of garden monuments published in Poland [17] and reissued two years ago.

A certain kind of justification for such an attitude in Poland may be connected with destructions of the entire historic substance during the Second World War and then the postwar nationalization which also included garden complexes, which, apart from conservation measures, also required adaptation to completely new purposes subordinated to new social requirements and even political ones. At the same time, the lack of sufficient funds limited most of these actions to "a group of more valuable layouts, which, for didactic purposes, would make it possible to reconstruct some kind of model solutions from each style epoch" [56] (p. 15).

It seems, however, that the permissibility of restitution in the Florence Charter defined in this way, also became a kind of passport for other practices, namely, the so-called "re-creation" [57] (pp. 101-130) and "creative conservation" [58] (p. 126). It should be remembered here that these are not new practices. They correspond to the former activities of brothers Henri and Achille Duchêne in France and Great Britain, as well as to creative German reconstructions from the 1920s and 1930s (Brühl, Herrenhausen, Sanssouci). They also refer to the concept of "creative monument conservation" (Schöpferische Denkmalpflege) which was introduced in 1929 by Rudolf Esterer. Years later, this attitude was characterized by Dieter Hennebo as the one which permitted "both in the care and restoration of historic gardens for personal creative interference and changes in order to meet the current utility requirements" [15] (p. 72).

Concerned about the "limitless creativity", which was accepted by links in the records of both the Venice Charter and the Florence Charter, German garden researcher Clemens Alexander Wimmer claims that although conservation of historic gardens cannot be done without creativity, it cannot be unlimited, because then it becomes harmful. At the same time, he proposed three criteria for the valorization and activities carried out in historic gardens. "Ethical evaluation" seems to be a special one among them. In the opinion of this 
researcher, it should be included in the Florence Charter which was also revised in this respect [32].

The discussion around this issue in relation to all monuments took place also in Poland and focused on two attitudes, i.e., conservative, represented in the mainstream of the discourse between Ksawery Piwocki who convinced others that "the authenticity of a work of art is connected not only with the form of a work, but also with its substance" [59] (p. 27) and Jan Zachwatowicz who noticed the need for reconstruction and believed that "it is necessary that the monument should have the fullest and really suggestive form" [60] (p. 49).

Nowadays, it is not without significance for this approach to think in terms of activating tourism to which nice-looking complete gardens contribute, despite the fact that tourism is becoming an increasing burden for them. Let us also not forget about the frequent "entanglement of heritage in contemporary purposes", or the created (sometimes for political reasons) "celebration of feelings and creation emotional images of the past, which in practice may mean opposition to the historic truth" [61], (p. 3).

Regardless of the assessment of the views and recommendations presented above as well as the research and activities carried out on their basis, the foundation of all of them should be a properly conducted "documentary evidence" analysis, which is mentioned by the Florence Chart and Nara Document on Authenticity. However, how to effectively use them in research on the history of gardens and in conservation practice to avoid undermining the obtained scientific results and activities undertaken? The next part of the article focuses on drawing attention to the most important issues which are connected with this topic in the context of authenticity.

\subsection{Analysis of Sources}

The role and importance of source materials in research and actions which are connected with monuments was noticed in the Venice Charter in the chapter on restoration, where we read: "The restoration in any case must be preceded and followed by an archaeological and historic study of the monument" [9] (Art. 9). The Florence Charter also says-as already mentioned-about "unimpeachable documentary evidence", but only in the context of justifying the restoration [1], Art. 16. An extended comment can be found in the Nara Document which highlights the properties of sources which may differ depending on the culture and even within the same culture. The Document also emphasizes their diversity which may concern the "form and design, materials and substance, use and function, traditions and techniques, location and setting, and spirit and feeling, and other internal and external factors. The use of these sources permits elaboration of the specific artistic, historic, social, and scientific dimensions of the cultural heritage being examined" [10] (Art. 11,13). References to the importance and scope of the use of sources for research and activities in the protection of the broadly understood heritage can also be found in the Burra Document and the XI'AN Declaration. Their summary, including all the main official documents, can be found in Appendix A.

However, it was the entry from the Florence Charter that provoked the reaction of many researchers who, like Hartmut Troll, rated the widely used in practical conservation of garden monuments and often thoughtless approach to sources as "naïve" and at the same time they expressed concern that the Florence Charter's message "may even support misuse of historic source material" [31] (p. 87). Stefan Schweizer went even further by saying that "in such a delicate matter as garden, iconographic sources often function as substitutes for the object. A large part of garden historiography is based on views and prints, which, due to insufficient consideration of conventions [ ... ] and various functions which were performed in the epoch, could be mistakenly taken as almost authentic evidence of historic reality" [27] (p. 2) [31] (p. 86). 


\subsubsection{Written Sources}

Referring to the above doubts about the meaning of sources and at the same time trying to answer the question posed in this article at the end of the section devoted to the issue of authenticity, we will start with the characteristics of written sources, including the group of herbaria, botanical and garden treatises, horticultural and agrotechnical guides as well as florilegia and plant catalogs. Firstly, it must be borne in mind that many of them had just a local influence and only some of them turned out to be, we would say, pan-European. Furthermore, the fact that some of them, especially the oldest ones, constituted indeed a summary of the contemporary knowledge of nature, but it was often based on ancient and medieval Arab works. Not everyone remembers that it is to the works of Columella and Pliny that we owe the so-called raised ridges and perches limited by wooden palisades or wicker fences. Additionally, the scientific basis for the experiments of a hydraulic character, thanks to which fountains and other water arts were powered, were provided by Arabic engineer al-Jazari, who, moreover, used the treatise of Heron of Alexandria [62]. Additionally, we ought to recall the fact that in the 16th century the famous work of Pietro de Crescenzi [63] in the version (as a manuscript in French in 1373, printed for the first time in German in 1471) which was translated into many European languages, including the Polish language, but without any comments, sometimes contained pieces of advice which were completely impractical due to climatic conditions and sun exposure in gardens located to the north of Europe, and, moreover, did not take into account the current knowledge of horticulture at the time of printing.

In written sources, we can also find a lot of information about plants, for example the aforementioned boxwood, which, as an effective evergreen and now easy to grow plant, is now planted in almost all regular gardens in Europe. However, when reading source materials carefully, we become aware of its late use in Europe to the north of the Alps (except for the British Isles, where it appeared thanks to the Romans) due to, inter alia, long-term dislike of boxwood (unpleasant smell, bitter honey and intoxicating properties) and even problems with its cultivation, for example in the 17th and 18th century Sweden, where it was frozen and in order to create decorative ground floors, local cowberries had to be used [5].

The absence of boxwood as a hedge plant or even non-existence of any hedges in the late-medieval gardens is also confirmed by a query which was conducted among the 15th century representations of gardens (both secular and symbolically religious) and which can be found in miniatures, drawings and paintings. We can see garden quarters which are framed by low walls, woven fences or wooden boxes, but never by hedges! When they appeared, in the case of border forms and decorative motifs, they were rarely made of boxwood (with the exception of Italy, Spain and England), which was confirmed by the work of French gardener of the three French kings Claude Mollet (1564-1649), i.e., "very few notable people wanted to have this plant in their gardens" [64] (p. 201). Additionally, although the knowledge of boxwoods in France, which however did not confirm their more widespread use, was revealed in Charles Estienne's treatise of 1554, which briefly mentioned that "boxwood hedges surround the garden and create opere topiaria" [65] (p. 29), nevertheless, a breakthrough for their later career in European gardens-according to Mollet-was to be the consent of Henry IV to plant boxwood in Saint-Germain-en-Laye in 1595 and then in Fontainebleau [64] (p. 202).

In the light of what was said about the introduction of boxwood into French gardens, there are reasonable doubts about the large-scale use of these plants for the re-creation of medieval gardens (see Figure 7), especially monastic ones, in almost all of Europe; see Figures 8 and 9. Even during the so-called reconstruction of Renaissance gardens on the example of Villandry, which were originally established before the mid-16th century. After the period of transformation into a landscape complex, they were re-established as "renaissance" in 1906 and then inscribed on the UNESCO World Heritage List as part of the Loire Valley complex in 2000; see Figure 10. We can find the effects of similar actions also in Poland, for example in the "renaissance" giardino segreto in Pieskowa Skała (see Figure 11), 
the "medieval" cloister of the Museum of Architecture in Wrocław (see Figure 12) as well as in the Wawel Royal Castle, where in recent years "royal gardens" with the use of boxwood were established in the 16th-century stylistics; see Figure 13.

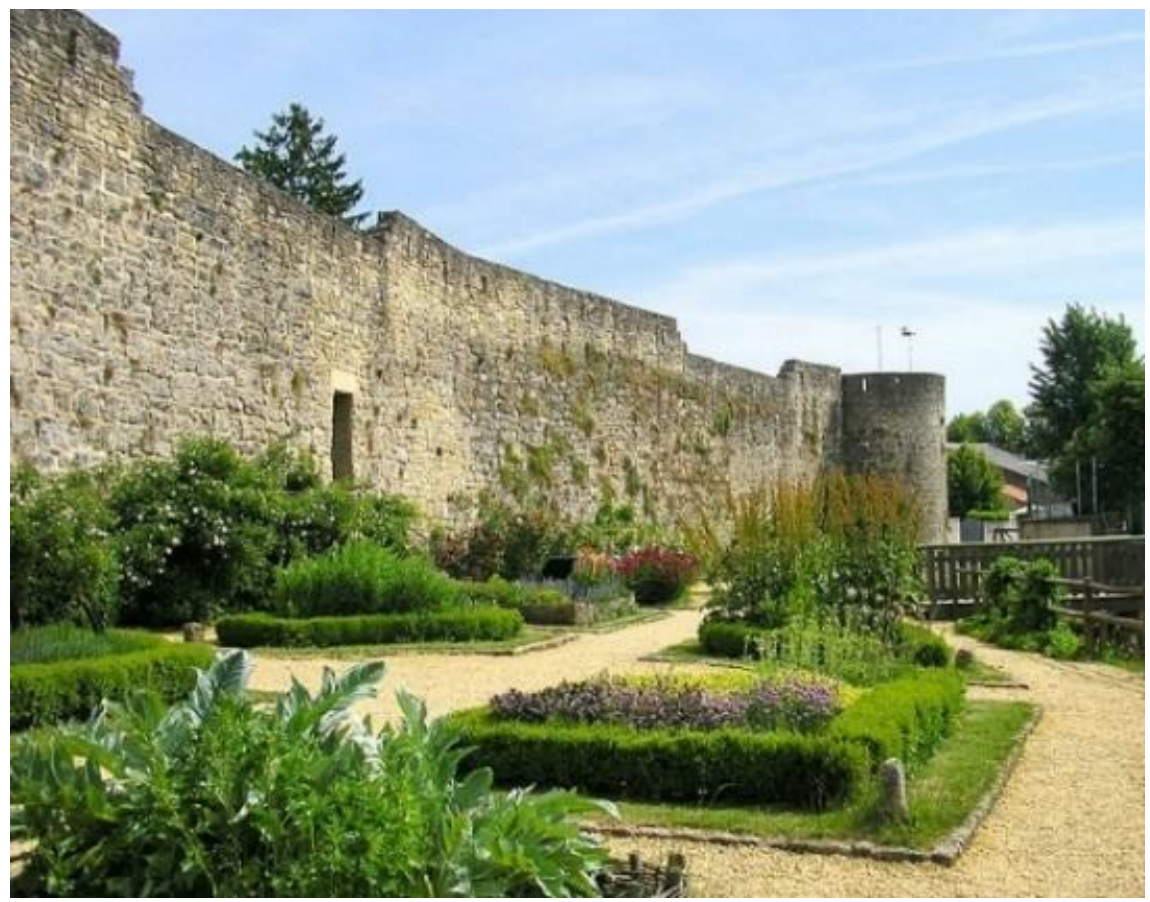

Figure 7. Medieval garden reconstructed with the use of box trees in front of the Rodemack city walls (Lothringen, Germany). Photo Feles, 2005; from (Public domain) https:/ / upload.wikimedia.org/wik ipedia/de/thumb/4/43/Mittelalterlicher_Garten.JPG/766px-Mittelalterlicher_Garten.JPG (accessed on 20 January 2021).

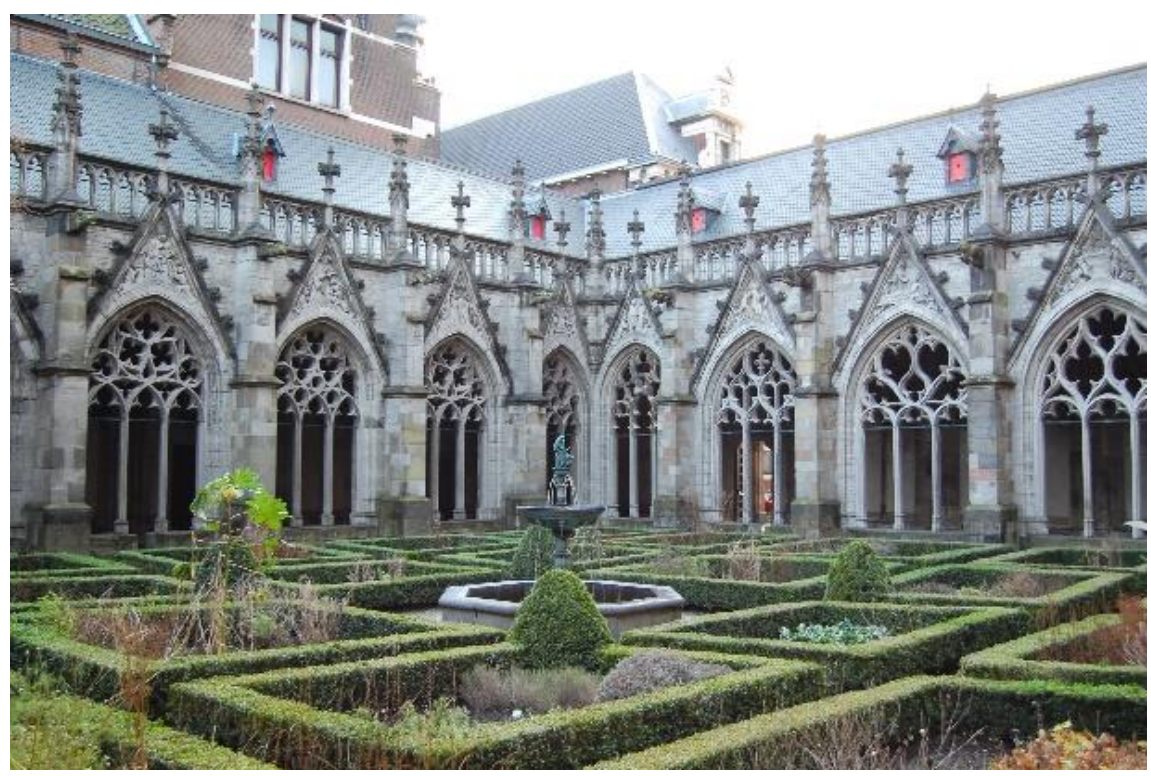

Figure 8. Pandhof, the monks' garden located at the bell tower of the Gothic St. Martin in Utrecht. Photo Moblio, 2011; from (Public domain) https://upload.wikimedia.org/wikipedia/commons /thumb/9/95/Kloostergang_Domkerk.JPG/800px-Kloostergang_Domkerk.JPG (public domain) (accessed on 20 January 2021). 


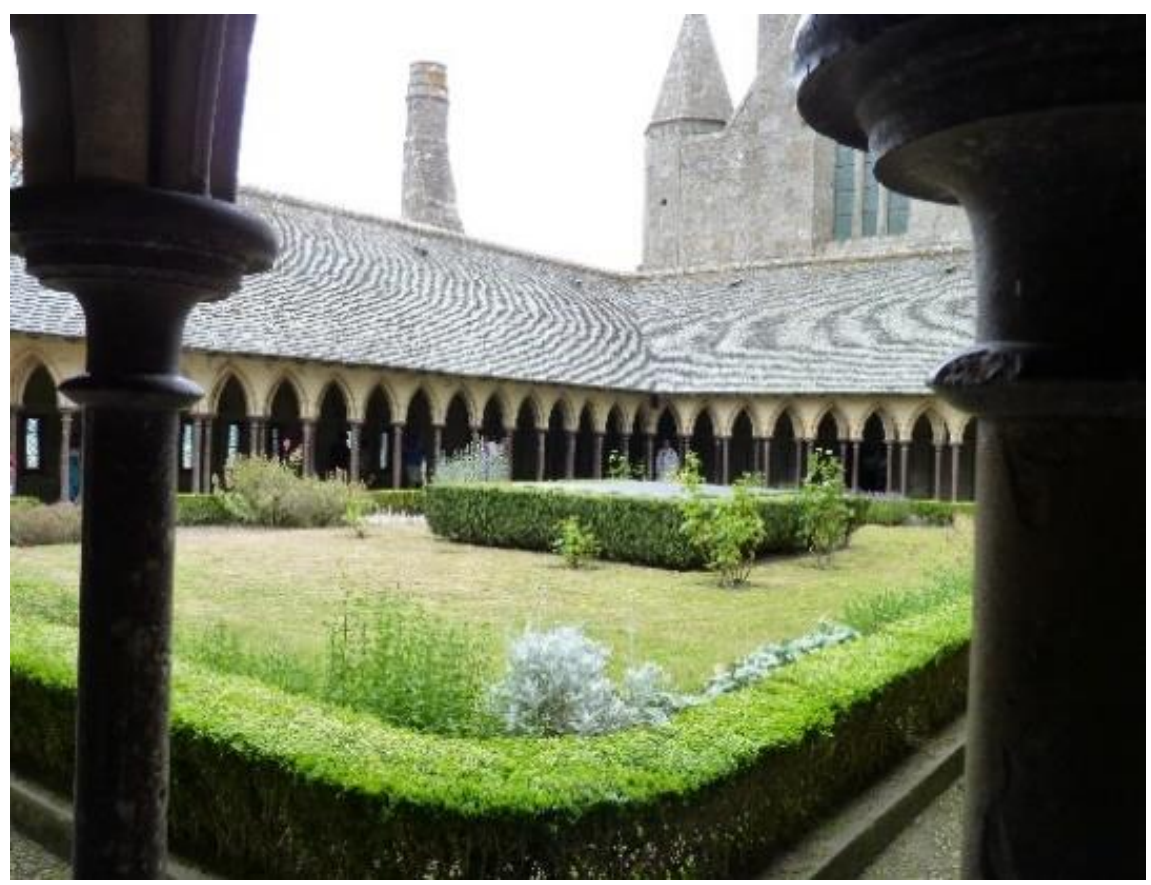

Figure 9. The courtyard of the medieval sanctuary of Mont-Saint-Michel (France). Fot. Libriothecaire; from (Public domain) https:/ / upload.wikimedia.org/wikipedia/commons /8/8b /Cloitre_abbaye _mont_saint_michel.jpg (accessed on 20 January 2021).

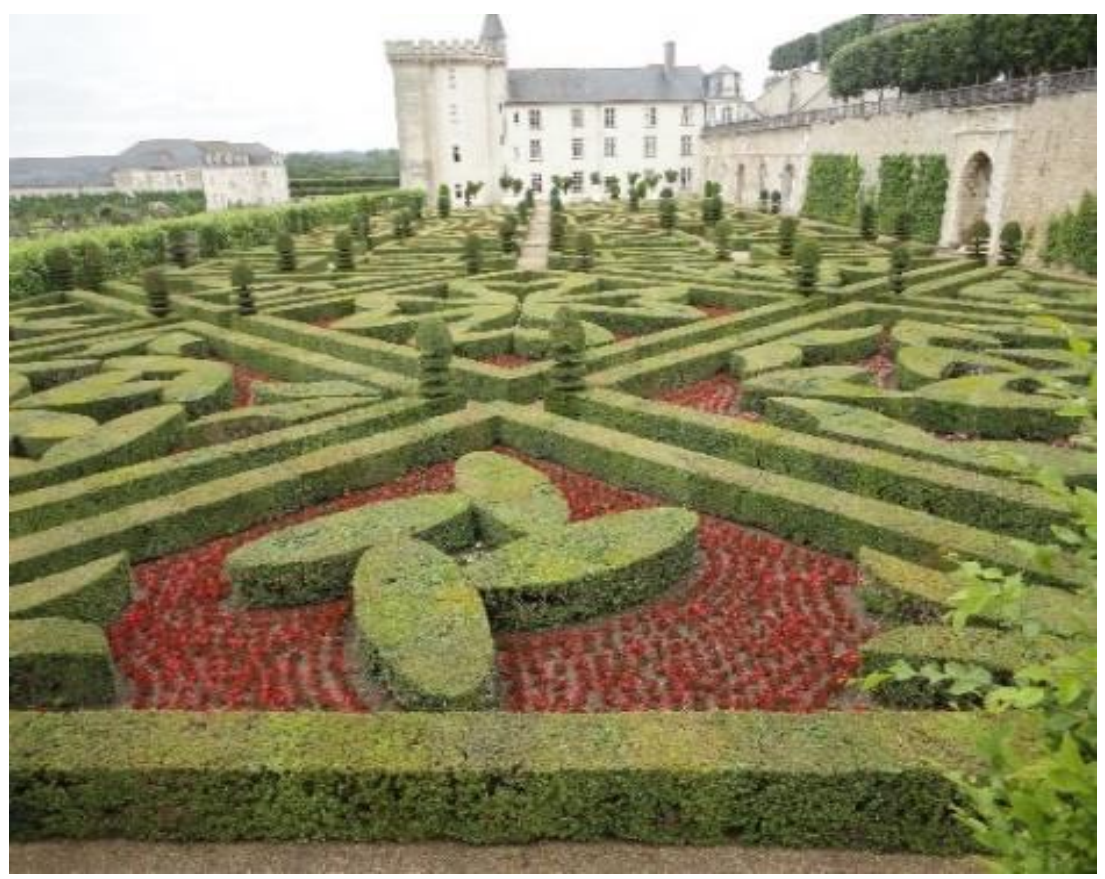

Figure 10. Fragment of the "Renaissance" gardens of Villandry (France), an example of the so-called creative conservation. Photo W. Brzezowski, 2016. 


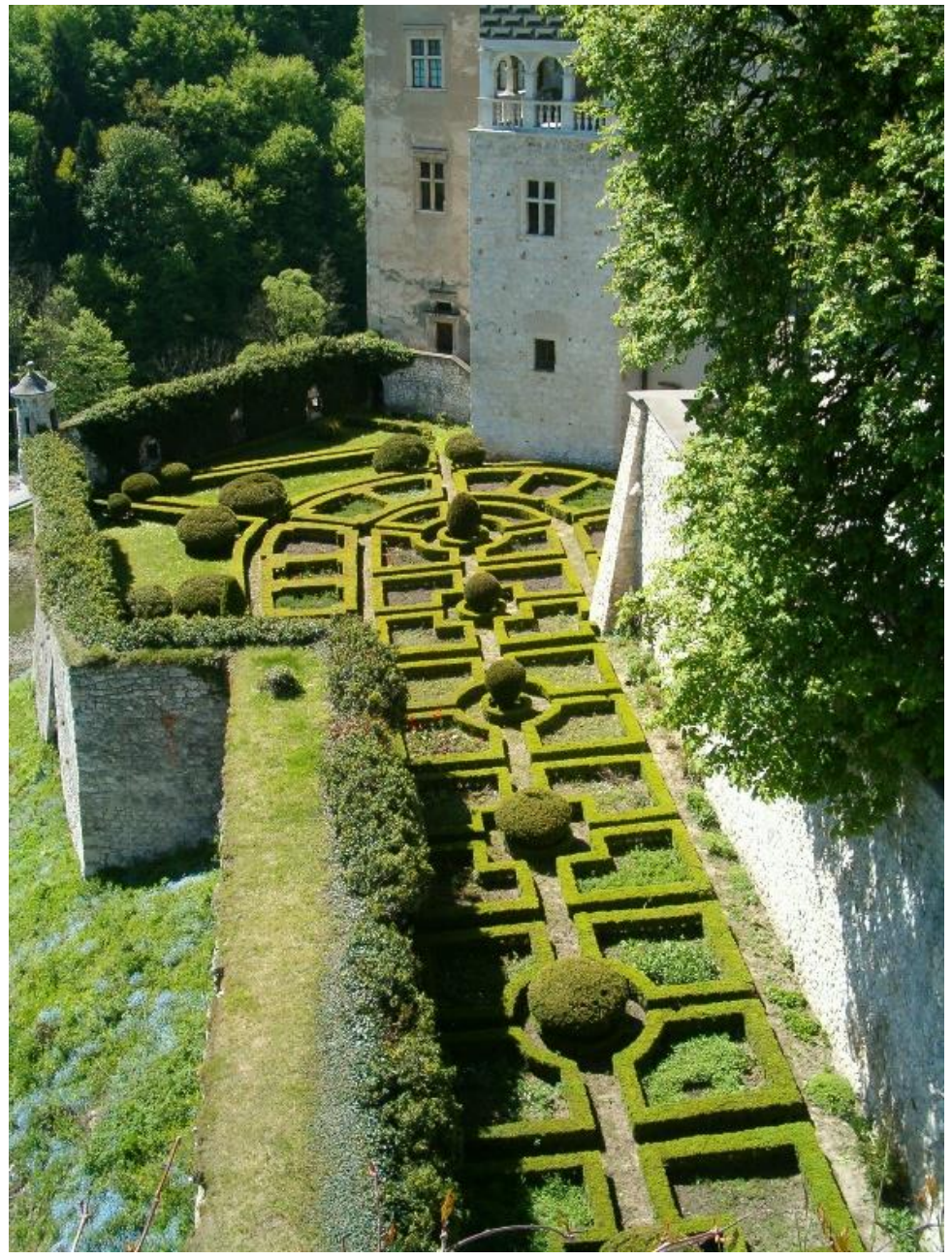

Figure 11. Giardino segredo in Piaskowa Skala (Polish), translation of the re-creation with the use of box trees. Fot. Piotr Górski, 2005; from (Public domain) https: / / commons.wikmedia.org/wiki/File: Pieskowa_Ska\%C5\%82a_Ogr\%C3\%B3d_01.jpg (accessed on 10 January 2021).

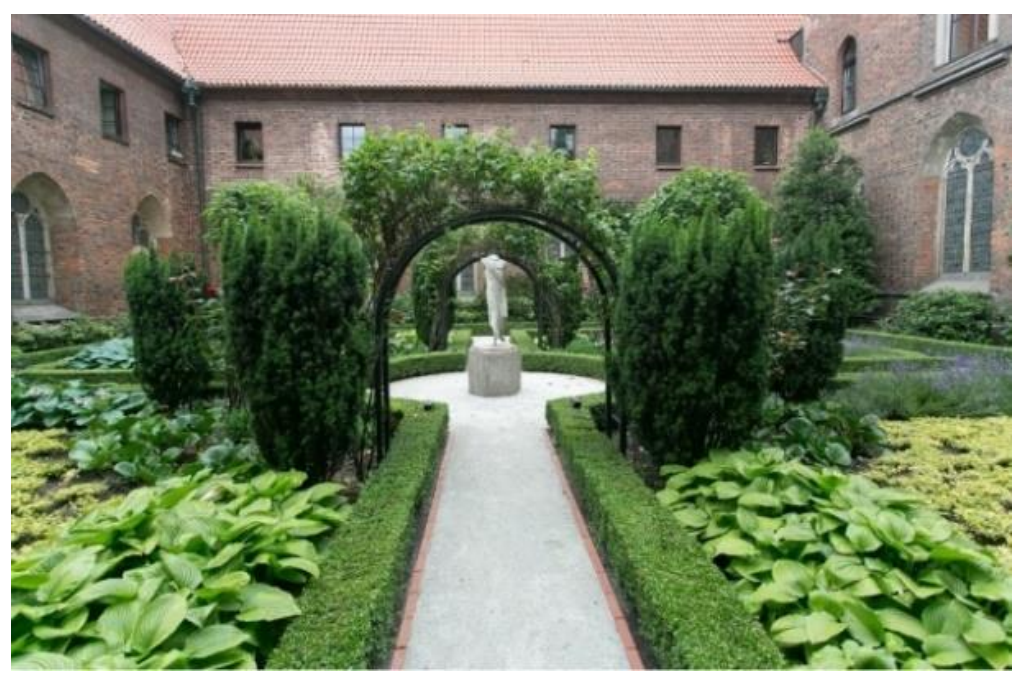

Figure 12. The courtyard of the Museum of Architecture in Wrocław (Poland), once a medieval Bernardine monastery. In the foreground, boxwood and funky. Photo M. Jagiełł 2016. 


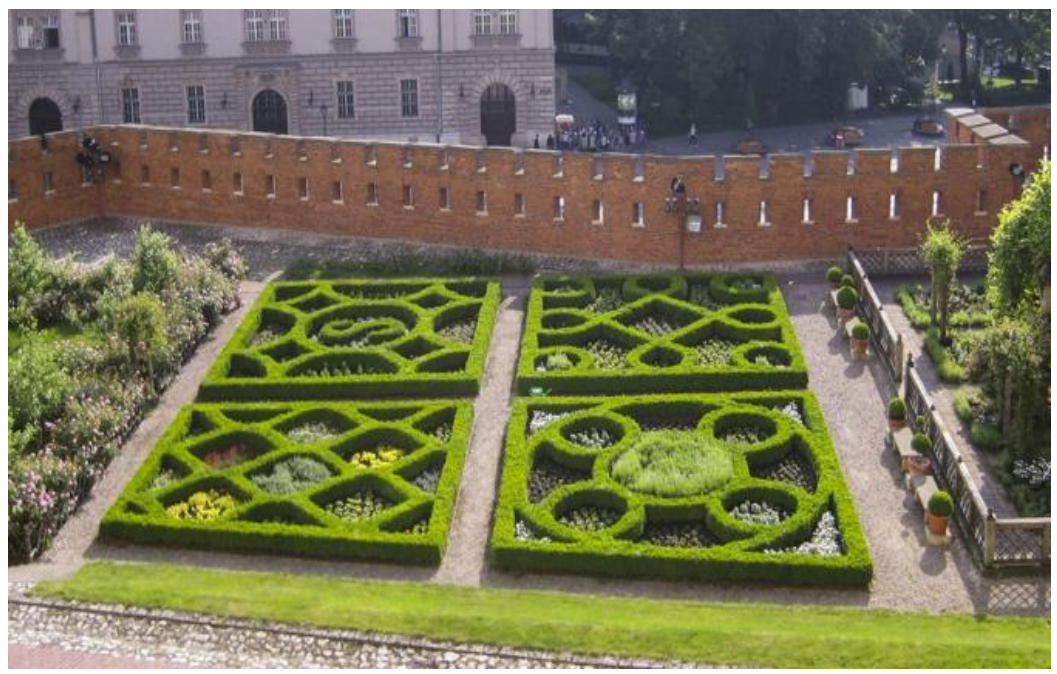

Figure 13. The "Renaissance" gardens of King Sigismund at Wawel (Krakow, Poland) reconstructed mainly with the use of boxwood. Photo M. Jagiełło, 2019.

Reading some old treatises allows us to find out which plants were once used to shape hedge forms, for example in the German language zone. So, in a book by doctor and astronomer Peter Lauremberg, which was entitled "Horticultura" and published in 1631, the author recommended the following plants for hedges: Liguster, rosemary, and southern mosquito shrub, and for higher forms - hawthorn, juniper, barberry, laurel and lilac [66] (p. 61). In a work of gardener Heinrich Hesse entitled "Neue Garten-Lust", published in Leipzig in 1696, we find a chapter on how to "gracefully secure the garden and make the best use of hedges" [67] (pp. 7-9, 389-390). We can also read there that the French think a lot about a hedge in the garden, so we in Germany must also arrange it." Later, the author claimed that "hedges and trees are the highest decoration of the garden" and recommended dogwood (e.g., for avenues planted on both sides with trees or creepers, whose shoots intertwine over the road creating a vault), ligustra, holly, and also (although rather for the kitchen garden) gooseberries, currants, barberry and roses [67] (pp. 7-9. It is worth keeping this information in mind when thinking about plants which will replace boxwood that is ruthlessly exterminated by Cydalima perspectalis.

Continuing the considerations on the authenticity of the botanical world, we should also pay attention to catalogs of plants which grow in the particular gardens (florilegia constituted such a subgroup for flowers). The practice of compiling this kind of lists, most often richly ornamented, was initiated by German physician and botanist Joachim Camerarius in "Florilegium", published in 1589 [68]. He established a sort of canon which contained a short catalog and descriptive part as well as the rich illustrative one. Unfortunately, some of these studies lost their illustrations, which is even more painful as the old names assigned to individual plants differ significantly from today's names and only by comparing these names with catalogs created in a similar period, is it possible to determine a species list of plants planted in European gardens at that time in individual regions or language zones. For Silesia, such a comparative analysis was carried out for two of the most famous Wrocław gardens, i.e., the mannerist one which belonged to doctor Laurentius Scholz [7] (pp. 113-138) and the baroque one whose owner was merchant Caspar Wilhelm Scultetus [69] (pp. 471-482) (see Figure 14). We only have lists of plants growing there along with the names, partly regional, which were adopted at that time. For Scholz's garden the aforementioned florilegia were such a reference, for Scultetus and his collection of citruses-Johann Christoph Volkamer's "Nürnbergische Hesperides" from 1708 [70]. 


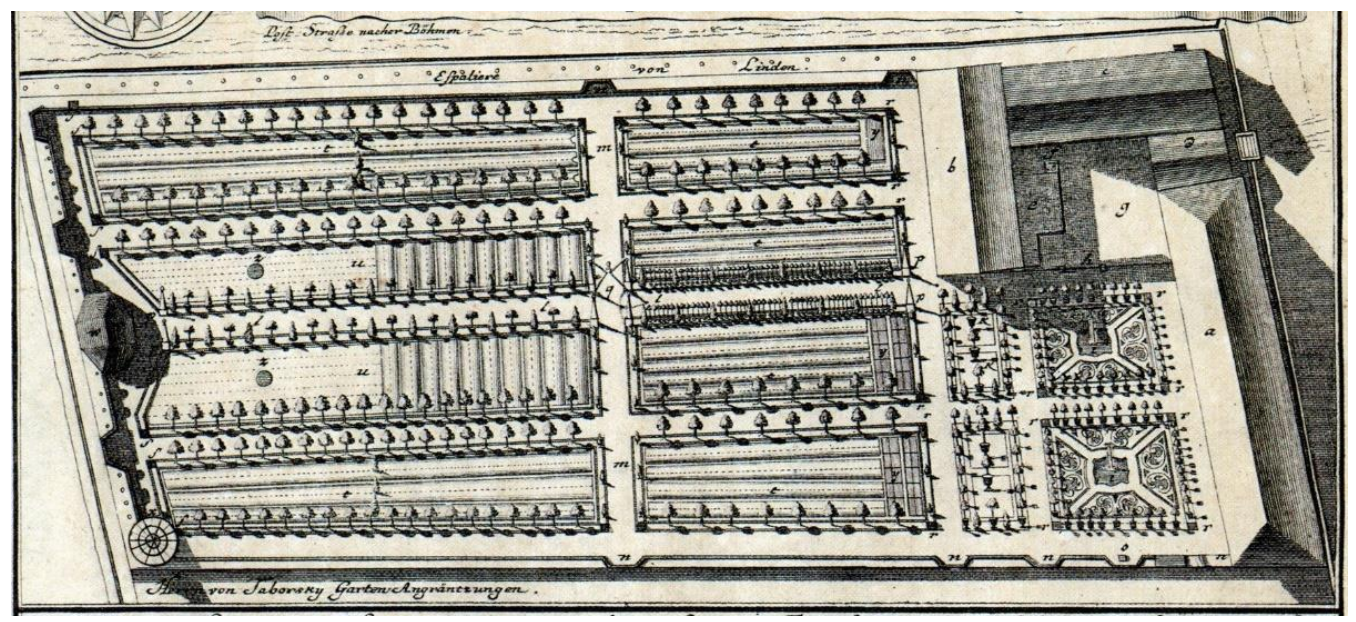

Figure 14. W. C. Scultetus' garden plan in Wrocław (Poland), 1731; from (Public domain) https: / / fotopolska.eu/765163,foto.html?s=1\&cx=904\&cy=649 (accessed on 2 February 2021).

When analyzing sources, we should also pay attention to the fact that today the extremely rich collections in state or university libraries, including, among other things, historic studies on gardens and horticulture, moreover often available online, say nothing about the actual access to these publications in the past. These expensive books, which were once printed in a limited number of publications, were available to owners and designers in a small number of titles. Moreover, some of those designers created and published their thoughts on gardens only on the "local market", dedicating them to wealthy investors. Only a careful analysis of these collections in terms of prior belonging to private or monastery libraries, as evidenced by ownership marks or other information proving the origin of these books and the way they traveled (antiquarian marks, marginal notes and donation entries), can provide indications about the character and the scope of their influence on the shape of the studied gardens. This kind of preliminary query, concerning the collections of the present Wrocław University Library, consisting of books and other prints which were previously owned by private collectors (nobility, aristocracy, but also rich burghers) as well as by monastic owners, was carried out by Wojciech Brzezowski [71].

When analyzing the content of such works, we should also take into account a completely different attitude of the people of that time to what we now call copyright. The studies devoted to gardening issues show the great ease with which their authors, very often without providing sources, included extensive fragments of books by their colleagues "in the trade" in their own publications (this is, of course, a topic for a separate discussion on the "authenticity" of these works in the source context).

The group of written sources important for the study of the history of gardens also includes economic inventories, often with lists of plants ordered for purchase or descriptions of investment activities (their character and costs) connected with gardens as well as chronicles, guides, letters, occasional prints (e.g., catalogs gardening exhibitions, advertisements for companies producing garden equipment) and press articles, essays, epic poems and poetry.

Instructive information is also provided by guidebooks, although not often used as a source. As an example, we can quote a fragment of one of them, which was written by August Zemplin in 1816, a health resort doctor in Szczawno (German: Bad Salzbrunn) in Silesia, who encouraged his patients to walk towards the castle and park complex in nearby Ksiaż, namely "Who would paint this wonderful, a one-of-a-kind route, where brick arches meet the rocks and a hiker seems to hover above the stream rippling in the depths among the rocks. Steep, massive rock reefs, once standing above each other, once again climb up steep walls, alternate with lush clumps of forest and tell us about some ancient devastation, as a result of which this valley was formed" [72] (pp. 134-135). Reading about "mighty reefs", "wild streams" and "ancient desolation", it is hard to resist the impression that both 
the author of this description and the others who wandered these routes were familiar with the feelings of sublimity experienced by the first explorers of Alpine trails, including Joseph Addison who recorded his impressions in the following way: "The Alps filled my mind with a pleasantly felt kind of horror" [73] (p. 261). Apart from the sublimity, which was treated in aesthetic categories from the 18th century, separating it from beauty and entering into a philosophical discussion (let us recall that it was Kant who believed that the sublimity should be sought in wild nature) [74] (pp. 121-122), to which we have a different attitude today (marked in the colloquial sense by exaltation and naive pathos), we have one more problem with the Ksiąz complex (but not only this) in the context of authenticity. It is the growth of vegetation, especially high vegetation, which covered most of the earlier view connections important for understanding the garden and changed the character of many places; see Figures 15 and 16. It seems that in this case, they can only be "reconstructed" by means of virtual reality, as shown by actions such initiatives taken for gardens, the physical reconstruction of which is impossible or unjustified; see Figures 17-19.

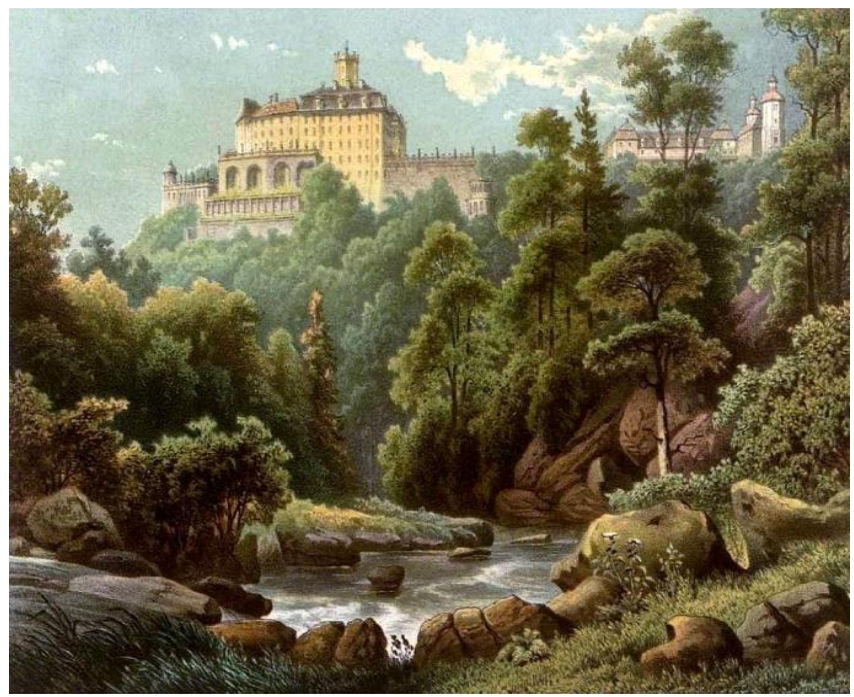

Figure 15. Książ (Silesia, Poland), view of the castle from the Pełcznica valley according to A. Duncker, c. 1860; from (Public domain) https:/ / pl.wikipedia.org/wiki/Plik:Schloss_Fuerstenstein_Sammlung _Duncker.jpg (accessed on 20 January 2021).

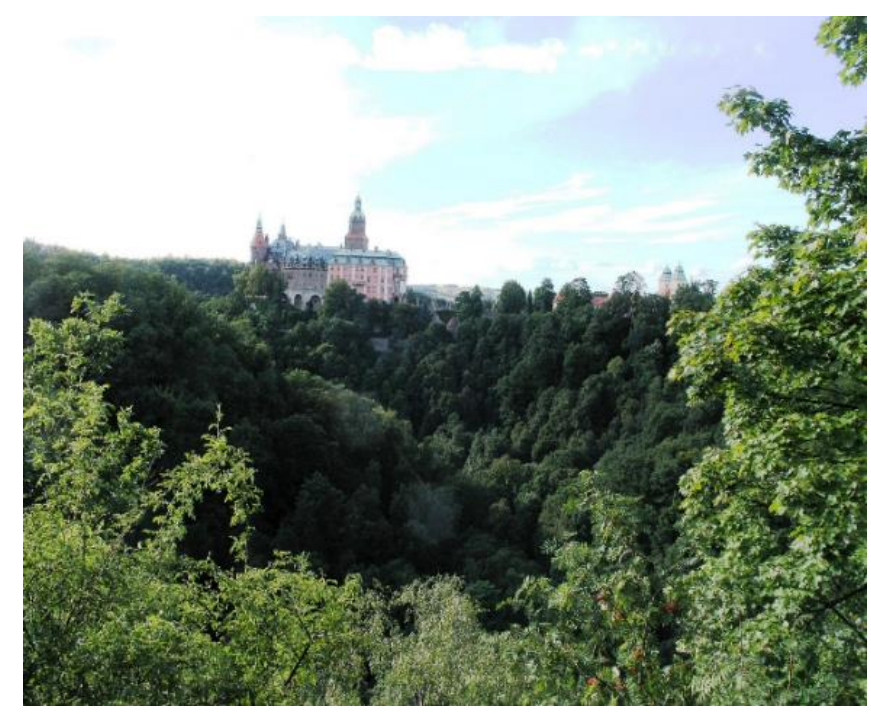

Figure 16. Książ (Silesia, Poland), view of the castle and the Pełcznica valley, the present state. Photo W. Brzezowski, 2013. 


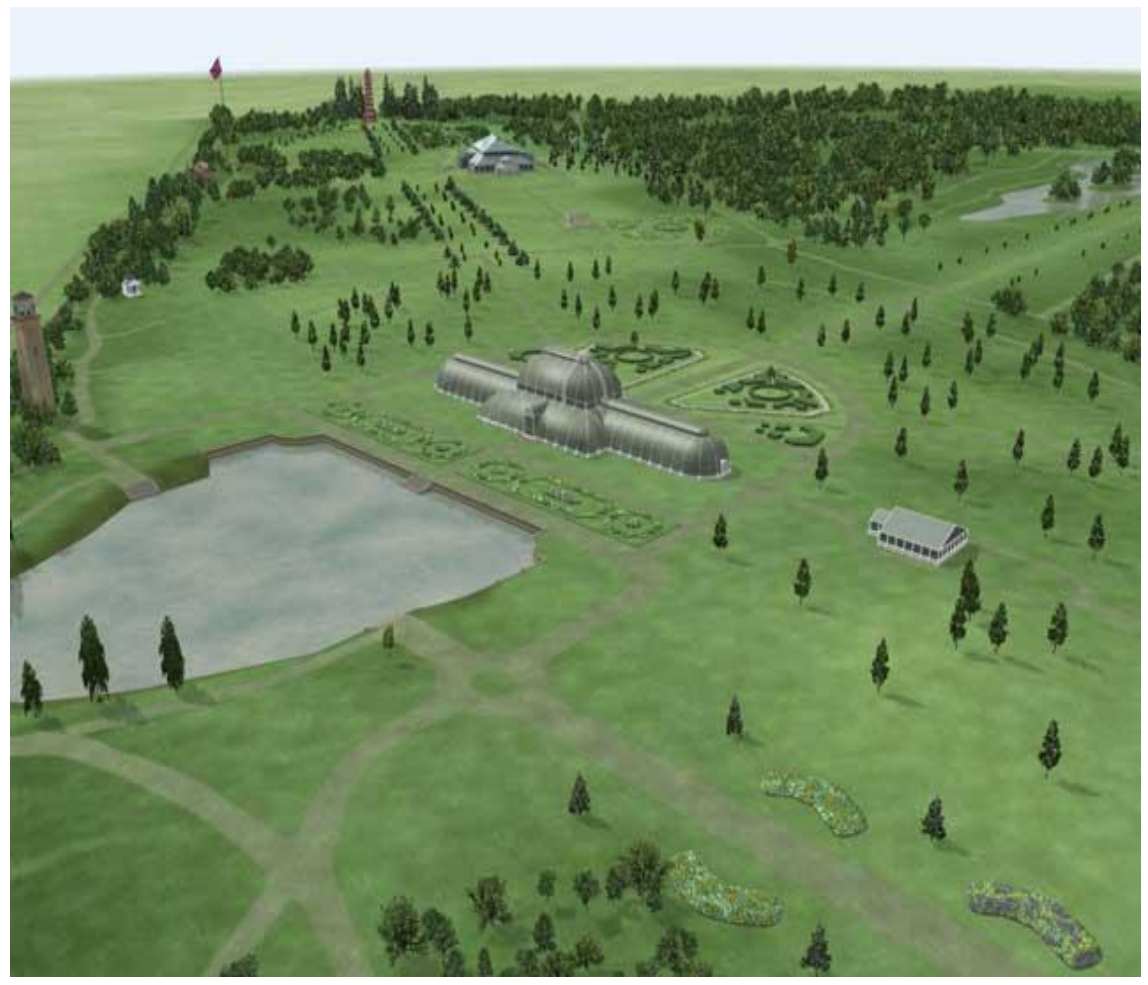

Figure 17. King's Visualisation Lab, King 's College London; from http:/ / www.kvl.cch.kcl.ac.uk/ke w.html (accessed on 20 January 2021).

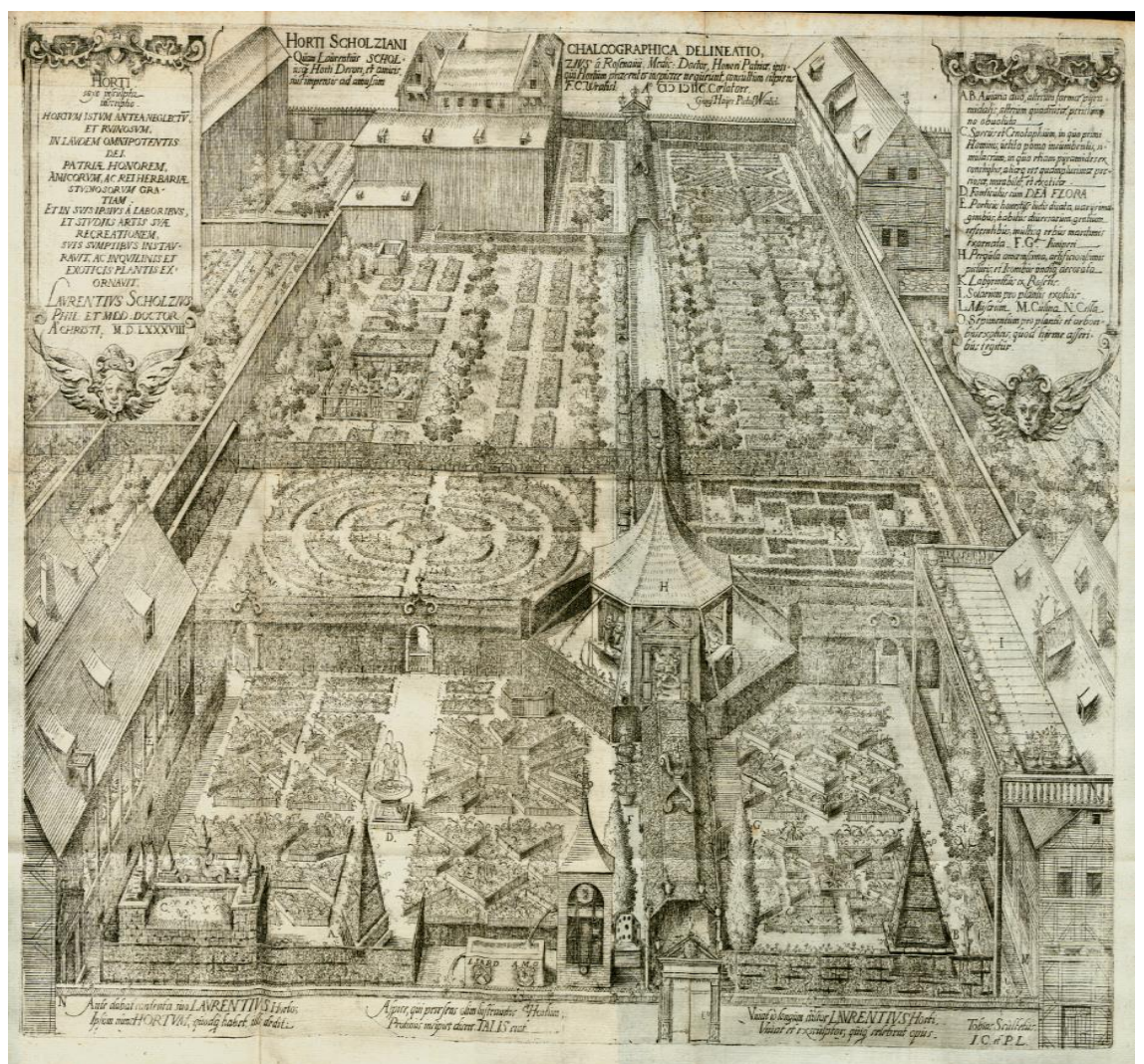

Figure 18. Laurentius Scholz's garden in Wrocław. An engraving by G. Hayer, 1598. Collections of the University Library in Wrocław, OSD, ref. 011185. 


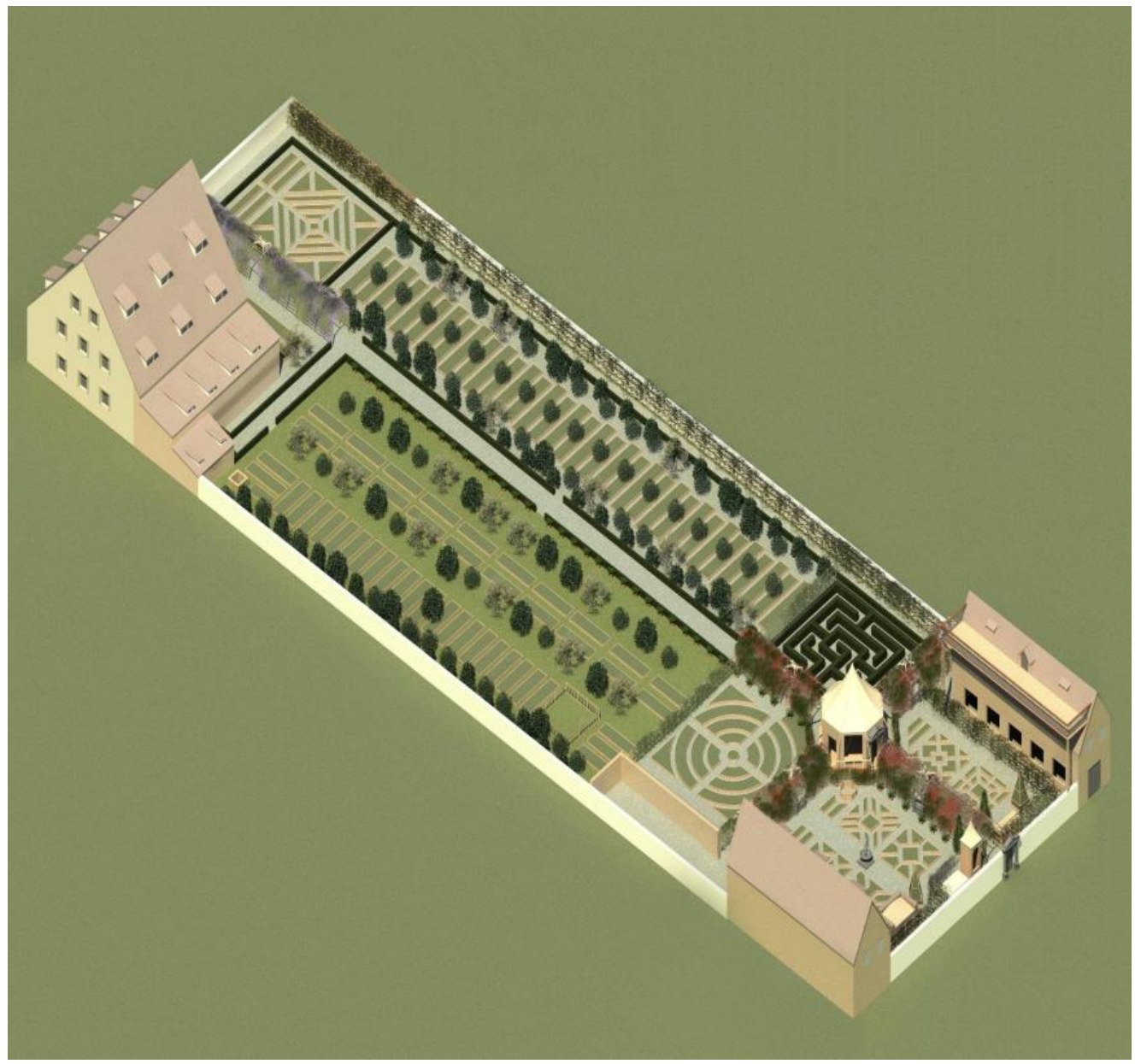

Figure 19. Virtual reconstruction of the axonometric view of the garden L. Scholz in Wrocław (Poland) based on an engraving by G. Hayer from 1588, analyzes of city plans and archaeological research, comp. by M. Jagiełł, K. Pietras, K. Lontkowska, 2013.

\subsubsection{Iconographic Sources}

Let us now focus on the second group of sources described as iconographic. We will start with comments about plans, vedute (understood as images of cities) and other views. Let us recall, then, that at the beginning, representations of gardens were most often connected with presentations of cities, towns, villages, castles, etc. The majority of them and the most precise in their iconographic message were made in the years 1629-1650 in the studio of Frankfurt engraver Matthäus Merian, first in the work entitled "Theatrum Europaeum" [75], and then in the 16-volume work entitled "Topographia Germaniae" which was continued after his death (until 1688), [76]. Among 1486 engravings placed there, we can also find those which show gardens in detail. This monumental study had its followers. At the beginning of the 18th century, the works by Georg Matthias Vischer (1628-1696), which covered the then Austria and then Styria in more detail, were published $[77,78]$. For Bavaria, such a collection containing over a thousand engravings made for 850 cities, monasteries, manors, castles and often with extremely detailed gardens, was prepared by Michael Wening (1645-1718) and his descendants in the years 17011726 [79], documenting their condition at the turn of the 18th century, i.e., the greatest baroque development. The above-mentioned examples were followed by, inter alia, Erik Dahlberg (1625-1703), a soldier in the service of the Swedish king Charles X Gustav and above all an excellent draftsman. On the basis of his sketches many etchings were made. They were included in two monumental studies glorifying the power of Sweden at that time, also through unusual and rich residential premises shown on numerous plans and 
views [80]. Dahlberg's inventory etchings were also used in the work of Samuel von Puffendorf, in which we can find several gardens from Poland [81]. We have similar documentation also for Silesia. It was developed in the years 1730-1760 in the form of several thousand colorful small but very detailed drawings by Friedrich Bernhard Werner (1690-1776) [82,83]. Similar in terms of subject matter, but graphical, was also made for baroque Vienna and its surroundings. It was prepared (in the years 1726-1731) by Austrian artist Salomon Kleiner [84] who specialized in vedute. We should also mention a group of works in which only gardens were presented collectively, such as "Ville e giardini di Roma" by Giovanni Battista Falda (1643-1678) [85] or the work of similar title "Li giardini di Roma con le loro piant" by Giacomo Giovanni Rossi (1627-1691) [86].

We cannot fail to mention the original design cards for the particular layouts as an invaluable iconographic source, however, they must always be verified by examining the scope of their actual implementation (also by means of archaeological research and by scanning the area). Studies which are also important are studies in the form of templates with visualizations of solutions relating to gardens of various functions and sizes as well as to various objects and forms of greenery filling them, which inspired both designers and investors. Such a series was developed for baroque gardens by, inter alia, Matthias Diesel [87], Antoine-Joseph Dezalier d'Argenville [45] and Jacques-François Blondel [88], and for the English-Chinese gardens, for example, Georges-Luis Le Rouge [89]. In Poland, Izabela Czartoryska and her "Myśli różne" [90] played an important role in this respect, whereas for the German gardens horticulture theorist Christian Cay Lorenz Hirschfeld [91].

It is also impossible to ignore the influence which individual complexes had, especially if they had monographic illustrated studies by Salomon de Caus (1576-1626) [92], for example for the gardens in Heidelberg Castle or Bad Muskau of Prince von PücklerMuskau [93], or when as pioneering they set generally accepted trends, often on a panEuropean scale, like Versailles. The knowledge about it was gained from numerous graphics prepared by, inter alia, Pierre Aveline (1656-1722), to whom we also owe an insight into other French baroque garden layouts.

The historical and cognitive benefits resulting from the analysis of this type of sources for the history of individual objects and regions seem obvious. They can also serve as a collection of information useful as a comparative material, if we take into consideration areas similar to each other in many ways, such as Bavaria and Silesia at the turn of the 18th century. Or when, on the basis of historic and environmental analyses, the zones of direct or indirect influence (of countries, artists, directions of their migration, and, finally, family or social ties of investors) are correctly identified. In this context, the importance of image memory and memories (from various journeys) is also significant, both in relation to garden designers and owners; in some cases, they are the same people, the so-called landscape amateurs. Here we have to take into account directions of journeys which change at different times and include them in diaries, journals, and correspondence. Personal contacts also turned out to be important, for example when passing on plants which were rare or new in Europe.

However, in-depth studies of the contents of various sources showed that we must treat them very carefully. For example, Swedish gardens from Dahlberg's work turn out to be in some cases an exaggerated projection behind which the then superpower policy of that country operated. Moreover, Werner's drawings, once burdened with many perspective errors [94] (pp. 63-70) and with strange abbreviations, sometimes constituted a kind of "visualizations" of plans which were not realized later.

Analyses of painting achievements also require a justified distance. Let us take the Polish example of Zygmunt Vogel, who, as commissioned by King Stanisław August Poniatowski, did a series of watercolor paintings documenting the earliest landscape gardens in Poland. Krystyna Sroczyńska, who dealt with the painting of this period, defined the properties of the artistic convention adopted by him, namely a decorative treatment of natural elements as frames for the presented architectural objects and the tendency to enlarge water mirrors, and thus artificially create the depth of the painting [95] 
(pp. 64-71). This shows that when considering the usefulness of artistic creativity for research on gardens, even the one which seems to have documentary features, we should refer to the evaluation of the overall oeuvre of the artist, preferably carried out from the perspective of research specific to art history.

Let us add that some of these inaccuracies can be verified, especially in terms of the plan, not only by means of archaeological research, but more and more often by using TLS and LIDAR scans, and first of all thanks to the analysis of maps. In the scope of our interest, the most accurate will be military topographic maps, although — which is obvious-all available cartographic materials should be analyzed. A rich collection of them concerning a significant part of Europe can be found on the Austrian portal mapire.eu [96]. Their precision and reliability results from their special purpose. They performed a role similar to that for which Erik Dahlberg prepared his inventory drawings for Poland, bearing in mind their military usefulness; see Figure 2.

For a slightly later period, such a group consists of military maps, the so-called Messtischblatten, which are very precise and compiled for German countries in the years 1876-1944. Of course, the cadastral plans are even more precise and detailed. They served tax purposes, hence the extraordinary detail of the plans connected with them, which was explained in extensive legends [97]. They were made in France in 1808 and in 1817 for Austria-Hungary, whereas the cadastre was also in force in the Kingdom of Prussia in 1819.

At the end of these considerations about sources, it should be emphasized that the usefulness of most of them should be limited to the benefits and research findings (registration and classification), whereas in the field of conservation, only to activities which do not raise suspicions of reconstruction actions.

\section{Discussion}

Forty years have passed since the adoption of the Florence Charter. Although it does not constitute a legal act but only a set of recommendations, it has left a significant mark on the actions carried out in historic gardens. Not always positive, but certainly inspiring for discussions, as evidenced by the exchange of views quoted in this article. They show that the recommendations of the Florence Charter were an expression of the then, not always up-to-date, state of knowledge and opinions on the issues of protecting garden heritage and another environmental and social awareness. Particular criticism was given to those provisions of the Charter that were related to the problem of maintaining authenticity. At the same time, the greatest controversy arises from allowing the restitution of historical gardens on the basis of source materials. The recommendations in the Florence Charter regarding the point exchange of plants (sometimes entire groups of plants) in order to maintain form stability are also opposed in many scientific and conservative communities. Following the spirit of the times, but also because of the critical attitude towards some parts of the records of the Florence Charter, national recommendations began to be developed independently of it. In 2007 such recommendations were prepared by the United Kingdom which in the document entitled Management and Maintenance-instead of making references to the Florence Charter-referred to the "Burra Charter" which was developed in 1979, but repeatedly updated (last time in 2013) and which consisted of a set of good practices (standards) in the scope of protection and management of Australian cultural heritage. It was accompanied by the "Code on the Ethics of Co-existence in Conserving Significant Places", which indicated the importance of the ethical attitude in cultural heritage management. When defining the value of cultural heritage, the "Burra Charter" also emphasizes "variability" by writing "Cultural significance may change as a result of the continuing history of the place" and adding "Understanding of cultural significance" may change as a result of new information" [13], Art.1, Explanatory notes. It also contains an important provision in the context of authenticity, i.e., "Changes to a place should not distort the physical or other evidence it provides, nor be based on conjecture" [13] (Art 3.2). 
Italy also followed its own path. Still in 1981, the local ICOMOS proposed its version of the charter entitled "Proposta per una carta del restauro dei giardini storici". The entry of this document, which constitutes the key to our considerations on authenticity, is quoted by Erik Schmidt, after Maria Pozzana, i.e., "the conservation intervention must take into account the entire process which is connected with the history of the garden because its structure and appearance materialized in this process" [98] (p. 236) after [29] (p. 87). This provision results in the fact that the garden should be treated as a palimpsest. The essence of this procedure was very aptly described by Italian art historian Isa Bella Barsali, referring it to Tivoli, i.e., "In these gardens, little was done in the 19th century. Negligence and lack of care during different periods caused uncontrolled growth of vegetation. Today, Tivoli is no longer a place which praises its creators-the Cardinals of the House of Este. It is entirely a different garden. It is a romantic forest in which we stumble over architectural fragments scattered like islands around the garden. [ . . . ] Today, Tivoli Gardens have a special beauty which was formed by many layers that have overlapped over the years. [ . . ] The problem with our inheriting gardens along with the complex Renaissance, Baroque and 19th century shape lies precisely in preservation of these features, not their restoration" [99] (p. 528); see Figure 20.

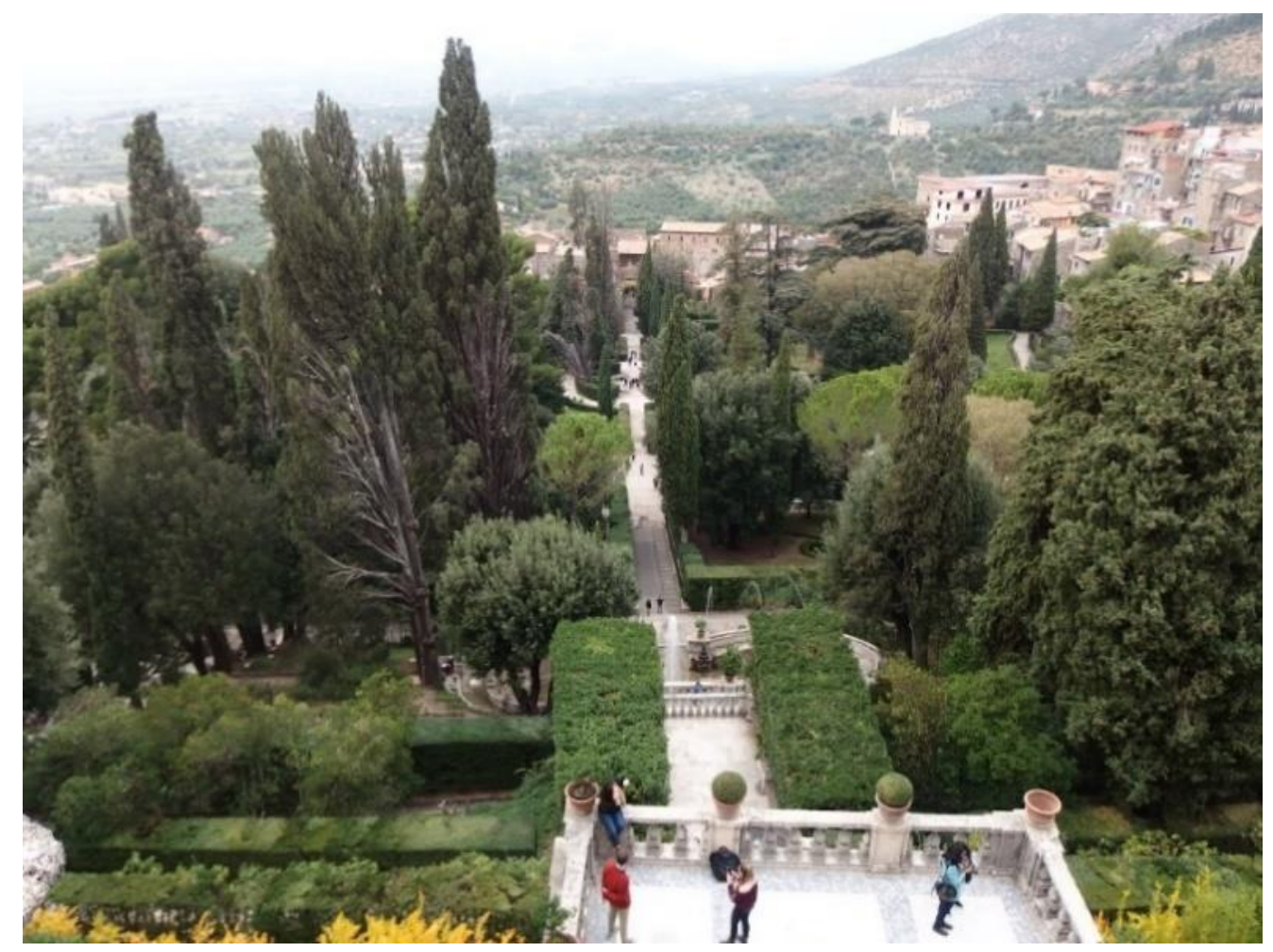

Figure 20. Villa d'Este gardens in Tivoli. Photo Palickap, 2017; from (Public domain) https:/ / upload .wikimedia.org/wikipedia/commons/a/a1/Tivoli\%2C_Villa_d\%27Este\%2C_giardino.jpg (accessed on 10 January 20210).

This approach to historic gardens is also supported by the current discussion on the definition of heritage, which is more and more often treated as "a process and not a type of resource" [Ashworth 2007, p. 32]. A change in heritage thinking was also made in the Burra Charter, where "places of cultural significance" were replaced by "sites and monuments" [13]. "This switched the emphasis from "stones and bones", material culture, towards the meanings of places, the significance that humans attribute to material culture [100] (p. 4).

Since the adoption of the Florence Charter, the semantic scope of the monument was also extended to new dimensions. As Polish historian Krzysztof Kowalski put it, 
referring to the findings of French researcher Nathalie Heinich, i.e., "the process described by Heinich led to a clear extension of the concept of a monument and the formation of a modern definition of the concept of heritage and new conservation strategies" [61] (p. 5) after [101] (pp. 17-21) as well as to the clear postmodern "dispersion of control over the past and its interpretations" [101] (p. 8.) "the world has changed" continues Kowalski "and along with postmodernity and the replacement of great stories with their local and often individual counterparts, the role of historic truth and authenticity of material substance has been weakened. Heritage has put emphasis differently, allowing for a multitude of interpretations and departing from the exclusivity which was lost by academic experts working on the matter of the past" [61] (p. 9).

Also important for the discussion about authenticity is the fact that more and more often considerations of gardens and other historic greenery layouts are included in the scope of regulations connected with sustainable management, which in the context of the observed changes (social, economic, and climate) seems to be a very urgent need [34,102]. For example, attention was paid to the detrimental influence of heat islands effect on entire groups of plants in historic gardens [36]. Additionally, on the activity of new pests and diseases which damage the historic stand as well as other plants, such as the aforementioned boxwood. This resulted in research on a new sustainable approach to the maintenance and restoration of historic gardens [33,34] and their role in the biodiversity protection strategy [35] as well as in maintaining the ecosystem structure of urban complexes [103]. Thus, to include the above-mentioned aspects in the considerations on the authenticity of historic greenery layouts, although so far most often on the basis of case studies.

With regard to the broadly understood heritage, the discussion on various aspects of authenticity has already started, initiating the project called "Journeys for Authenticity" on the initiative of ICOMOS, conceived as "platform for open discourses sharing ideas, solutions, and discussion about the concept of authenticity. Formats of communication might range from posters, live feeds, blog posts, reports, PowerPoints, video interviews or presentations, for example [104]. The ICOMOS Emerging Professionals Working Group (EPWG) hopes that the Journeys to Authenticity could be an opportunity for collaboration and mentorship between established ICOMOS members and emerging professionals, enabling intergenerational dialogue about these concepts and encouraging the use of diverse communication media and strategies" [105]. It seems that at the beginning it would be worth considering, analyzing, and perhaps using the existing provisions on authenticity contained in various official documents. The list of them is included in Annex B.

Let us also mention the fact that ICOMOS addressed the issues of heritage protection in the context of sustainable development, declaring the development of Sustainability Policy in 2019. In this context, it seems important to prepare recommendations regarding historic greenery layouts by researchers and conservators dealing with historic greenery, perhaps as part of ICOMOS-IFLA.

\section{Summary}

In the light of all that is presented in this article, do we need a new Florence Charter? It seems that there is no clear answer to this [29]. If so, it should, in our opinion, meet one essential condition. Its construction should be carefully considered so that, like the Burra Charter, it would be logical and transparent, and above all, flexible enough, and thus would enable periodic updating. Perhaps by analogy to the aforementioned "opera aperta", we should think of "carta aperta"?

Certainly, one should refer to all the most important controversies that arise from some of Florence Charter's recommendations. Then, take into account the experiences identified in this text resulting from the impact on heritage protection of other official documents. Especially in those aspects that relate to the issue of authenticity, as highlighted in this article.

Its establishment should be preceded by a further, thematically ordered discussion related to the protection of historic greenery assumptions, updated with the spirit of the 
transformations that we observe, in order to take into account the progress in understanding the theory and management of cultural heritage. Furthermore, by a discussion conducted as widely interdisciplinary as possible, including the field of sustainable development in relation to maintaining biological diversity and ecology [35]. The need for such a discussion is forced not only by changes in the approach to heritage, social changes or technological development, but also-which is becoming more and more important and urgent-those related to climate change. A model of such a procedure is presented in the diagram; Figure 21.

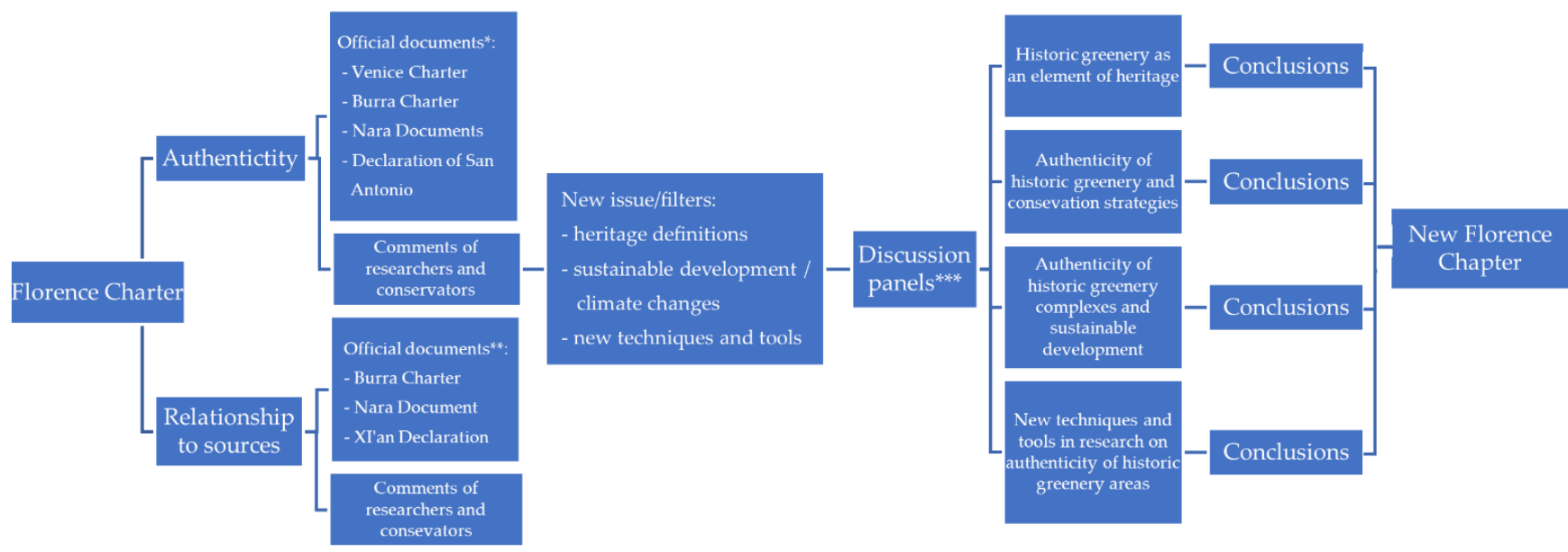

* Appendix A

** Appendix B

*** Detailed topics divided into four panels are presented in Appendix C

Figure 21. A diagram showing the results of the research and the method of further proceeding to prepare a New Florence Charter.

As part of this model, we propose four panels in which discussions about the new Florence Charter could be held:

1. Historic greenery as an element of heritage;

2. Authenticity in historic green complexes in research and conservation strategies;

3. Authenticity of historic green complexes and sustainable development;

4. New techniques and tools in research on the authenticity of historic greenery layouts.

A detailed range of topics for each panel is presented in Appendix C. Some of these discussions could be held under the auspices of UNESCO, for example within the "Journays for Authenticity" program. The place of considerations covering panel III. it could be for example the special issues of "Sustainability".

Funding: This research received no external funding.

Institutional Review Board Statement: Not applicable.

Informed Consent Statement: Not applicable.

Data Availability Statement: Not applicable.

Conflicts of Interest: The author declares no conflict of interest. 


\section{Appendix A}

Official Doctrinal Documents

Authenticity

NO. $\quad$ DOCUMENT

1. $\quad$ Venice Charter, 1964 *

(International Charter for the Conservation and Restoration of Monuments and Sites)

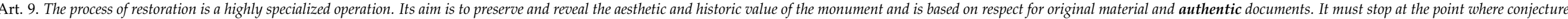
begins

$2 . \quad$ The Burra Charter 1979/1981/1988/1999/2013

Art. 3.2. Changes to a place should not distort the physical or other evidence it provides, not be based on conjecture.

Explanatory Notes to Art. 5.2. A cautions approach is needed, as understanding of cultural significance may change.

3. Florence Charter, 198

Art. 9. The authenticity of a historic garden depends as much on the design and scale of its various parts as on its decorative features and on the choice of plant or inorganic materials adopted for each of its parts.

Art. 11... the preservation of the garden in an unchanged condition requires both prompt replacements when required and a long-term programme of periodic renewal ..

Art. $12 . .$. with the aim to determine the species initially grown and to preserve them.

Art. 21. The work of maintenance and conservation, the timing of which is determined by season and brief operations which serve to restore the garden's authenticity, must always take precedence over the requirements of public use.

$4 . \quad$ Nara Document on Autenticity, 1994

Art. 9. Knowledge and understanding of these sources of information, in relation to original and subsequent characteristics of the cultural heritage, and their meaning, is a requisite basis for assessing all aspects of authenticity.

Art.10. Authenticity, considered in this way and affirmed in the Charter of Venice, appears as the essential qualifying factor concerning values. The understanding of authenticity plays a fundamental role in all scientific studies of the cultural heritage, in

conservation and restoration planning, as well as within the inscription procedures used for the World Heritage Convention and other cultural heritage inventories.

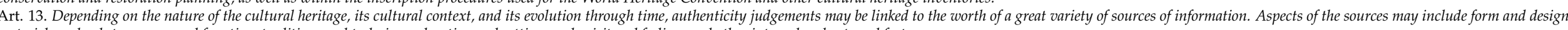

materials and substance, use and function, traditions and techniques, location and setting, and spirit and feeling, and other internal and external factors.

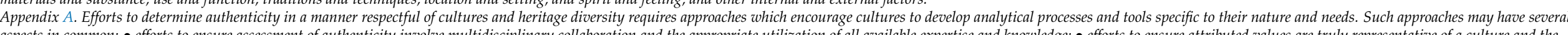

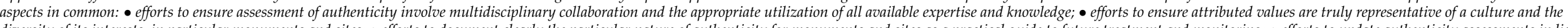

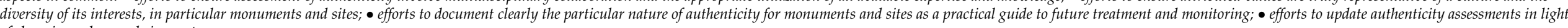
of changing values and circumstances.

5. The Declaration of San Antonio (1996)

\section{Art. B.}

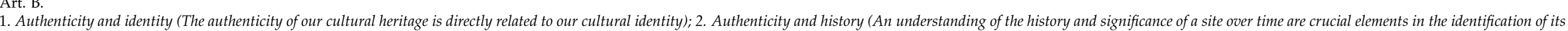

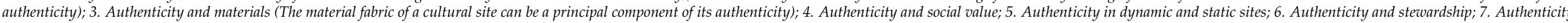
and economics.

Art. C.

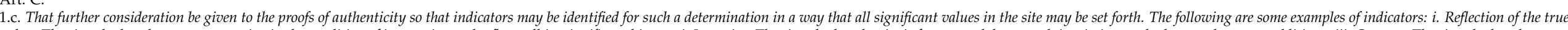
value. That is, whether the resource remains in the condition of its creation and reflects all its significant history. i. Integrity. That is, whether the site is fragmented; how much is missing, and what are the recent additions. iii. Context. That is, whether the context andor the environment correspond to the original or other periods of significance; and whether they enhance or diminish the significance. iv. Identity. That is, whether the local population identify themselves with the site, and whose ide tity the site

reflects. v. Use and function. That is, the traditional patterns of use that have characterized the site.

Art. C.

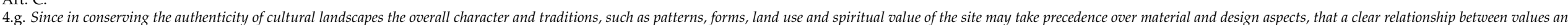
the proof of authenticity be established.

4.h. That expert multi-disciplinary assessments become a requirement for the determination of authenticity in cultural landscapes, and that such expert groups include social scientists who can accurately articu-late the values of the local communities. 4.i. That the authenticity of cultural landscapes be protected prior to major changes in land use and to the construction of large public and private projects, by requiring responsible authorities and financing organizations to undertake environmental impact studies that will lead to the mitigation of negative impacts upon the landscape and the traditional values associated with these sites. 


\section{Appendix B}

\section{Official Doctrinal Documents \\ Relationship to Sources}

NO. DOCUMENT

1. Burra Charter 1979/1981/ 1988/1999/2013

Art. 6.1. The cultural significance of a place and other issues affecting its future are best understood by a sequence of collecting and analysing information before making decisions.

Art. 19. Restoration is appropriate only if there is sufficient evidence of an earlier state of the fabric.

2. $\quad$ Florence Charter, 1981

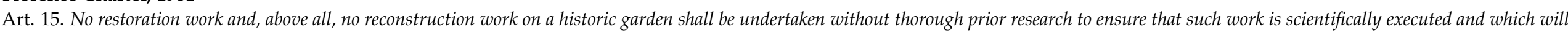
involve everything from excavation to the assembling of records relating to the garden in question and to similar gardens.

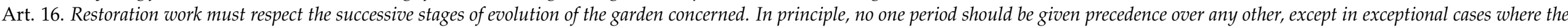
degree of damage or destruction affecting certain parts of a garden may be such that it is decided to reconstruct it on the basis of the traces that survive or of unimpeachable documentary evidence.

3. Nara Document on Autenticity, 1994

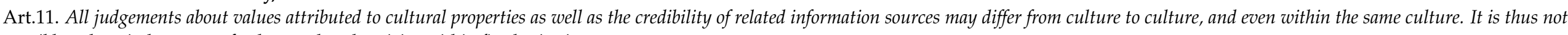
possible to base judgements of values and authenticity within fixed criteria.

4. XI'AN Declaration on the conservation of the setting of heritage structures, sites and areas, 2005

Art. 3. Understanding, documenting and interpreting the setting is essential to defining and appreciating the heritage significance of any structure, site or area.

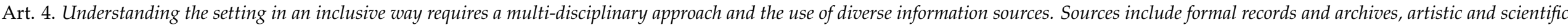

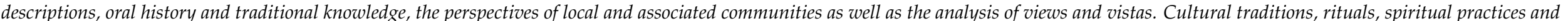

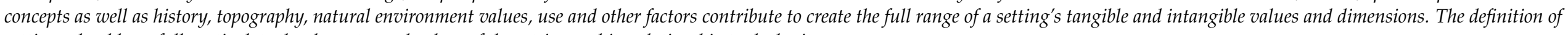
settings should carefully articulate the character and values of the setting and its relationship to the heritage resource. 


\section{Appendix C}

\begin{tabular}{|c|c|}
\hline \multicolumn{2}{|l|}{ Topics for Discussion } \\
\hline \multirow{11}{*}{$\begin{array}{l}\text { I. Historic greenery } \\
\text { as an element of heritage }\end{array}$} & 1. "Garden as a place of change" (opera aperta, palimpsest) versus "garden as a place of remembrance". \\
\hline & 2. "Garden existence" in research on the authenticity of gardens versus adaptation to contemporary needs. \\
\hline & 3. Garden as a scientific and engineering project in the context of authenticity. \\
\hline & 4. Old agrotechnical methods and techniques as a research subject and the conservation issue in the context of authenticity. \\
\hline & 5. Historic green areas as a subject of interdisciplinary research. \\
\hline & 6. Spirit of Place in research on the authenticity of historic greenery areas. \\
\hline & 7. Historic greenery areas as an element of heritage in the postmodern narrative. \\
\hline & 8. Historic greenery areas in the discussion about heritage and new conservation strategies/models. \\
\hline & 9. The importance of ethical attitudes in the management of cultural heritage in the context of historical green areas. \\
\hline & 10. Cultural conditions in the assessment of the value and authenticity of historical green areas. \\
\hline & 11. Authenticity of historical green areas in the light of social identification. \\
\hline \multirow{6}{*}{$\begin{array}{l}\text { II. Authenticity of historic green areas in } \\
\text { research and conservation strategies }\end{array}$} & 1. Conservation creation/creative conservation in the context of authenticity considerations. \\
\hline & 2. The use of sources in research on the authenticity of historic greenery areas and in conservation practice (written sources). \\
\hline & 3. The use of sources in research on the authenticity of historic greenery areas and in conservation practice (iconographic sources). \\
\hline & 4. The use of sources in research on the authenticity of historic greenery areas and in conservation practice (cartographic sources). \\
\hline & 5. Authenticity of the natural world of historic greenery areas in the context of source research. \\
\hline & $\begin{array}{l}\text { 6. Authenticity of the natural world of historic greenery areas as a subject of research and conservation practice in the context of climate change and } \\
\text { new diseases and parasites threats }\end{array}$ \\
\hline \multirow{4}{*}{$\begin{array}{l}\text { III. Authenticity of historic greenery } \\
\text { areas and sustainable development }\end{array}$} & $\begin{array}{l}\text { 1. A sustainable approach to maintaining and } \\
\text { restoring historic green areas, taking into account aspects related to authenticity. }\end{array}$ \\
\hline & $\begin{array}{l}\text { 2. The role of historic greenery in the } \\
\text { strategy of protecting biological diversity and its authenticity. }\end{array}$ \\
\hline & $\begin{array}{l}\text { 3. Historic greenery as an element of green } \\
\text { infrastructure of cities. }\end{array}$ \\
\hline & $\begin{array}{l}\text { 4. The influence of tourism on maintaining } \\
\text { authenticity of gardens. }\end{array}$ \\
\hline \multirow{2}{*}{$\begin{array}{l}\text { IV. New techniques and tools in } \\
\text { research on authenticity of historic } \\
\text { greenery areas }\end{array}$} & $\begin{array}{l}\text { 1. Possibilities and importance of research on historic greenery areas conducted with the use of modern techniques and tools (LIDAR, TSL), } \\
\text { electromagnetic conductivity (EM), ground-penetraiting radar (GPR) }\end{array}$ \\
\hline & $\begin{array}{l}\text { 2. Historic greenery areas and virtual reality, } \\
\text { opportunities and threats to authenticity. }\end{array}$ \\
\hline
\end{tabular}




\section{References}

1. ICOMOS-IFLA. Historic Gardens-The Florence Charter. 1981. Available online: https://www.icomos.org/images/DOCUME NTS/Charters/gardens_e.pdf (accessed on 7 September 2020).

2. ICOMOS-IFLA. Document on Historic Urban Parks. 2017. Available online: https://www.icomos.org/images/DOCUMENTS/ General_Assemblies/19th_Delhi_2017/Working_Documents-First_Batch-August_2017/GA2017_6-3-2_HistoricUrbanPublicP arks_EN_final20170730.pdf (accessed on 9 September 2020).

3. Agenda 21. Available online: https://sustainabledevelopment.un.org/content/documents/Agenda21.pdf (accessed on 8 September 2020).

4. Jagiełło, M.; Brzezowski, W. Autentyzm a Rekonstrukcja Zabytkowych Zespołów Ogrodowych. In Dziedzictwo Architektoniczne: Rekonstrukcje i Badania Obiektów; Łużyniecka, E., Ed.; Oficyna Wydawnicza Politechniki Wrocławskiej: Wrocław, Poland, 2017; pp. 74-84. Available online: https://www.dbc.wroc.pl/publication/41252 (accessed on 10 January 2021).

5. Jagiełło, M.; Brzezowski, W. Nie Tylko Bukszpany. O Autentyzmie Ogrodowej Szaty Roślinnej w Formach Żywopłotowych i Topiarycznych. In Dziedzictwo Architektoniczne: Restauracje i Adaptacje Zabytków; Łużyniecka, E., Ed.; Oficyna Wydawnicza Politechniki Wrocławskiej: Wrocław, Poland, 2018; pp. 23-40. Available online: https://www.dbc.wroc.pl/publication/86547 (accessed on 10 January 2021).

6. Jagiełło, M.; Brzezowski, W. Autentyzm Świata Przyrodniczego w Ogrodach Europejskich: Rośliny Egzotyczne. In Dziedzictwo Architektoniczne: W Kręgu Świata Przyrodniczego i Budowli Miejskich; Łużyniecka, E., Ed.; Oficyna Wydawnicza Politechniki Wrocławskiej: Wrocław, Poland, 2019; pp. 5-16. Available online: https://www.dbc.wroc.pl/publication/142344 (accessed on 10 January 2021).

7. Jagiełło, M.; Brzezowski, W. Ogrody na Śląsku. T. 1, Od Średniowiecza do XVII Wieku; Oficyna Wydawnicza Politechniki Wrocławskiej: Wrocław, Poland, 2014.

8. Brzezowski, W.; Jagiełło, M. Ogrody na Śląsku. T. 2, Barok; Oficyna Wydawnicza Politechniki Wrocławskiej: Wrocław, Poland, 2017.

9. ICOMOS. International Charter for the Conservation and Restoration of Monuments and Sites (the Venice Charter 1964). Available online: https:/ / www.icomos.org/charters/venice_e.pdf (accessed on 8 September 2020).

10. ICOMOS. The Nara Document on Authenticity. 1994. Available online: https://www.icomos.org/charters/nara-e.pdf (accessed on 8 September 2020).

11. The London Charter for the Computer-Based Visualisation of Cultural Heritage. 2008. Available online: https:/ /www.londonch arter.org/index.html (accessed on 8 September 2020).

12. ICOMOS, Xi'an Declaration on the Conservation of the Setting of Heritage Structures, Sites and Areas. 2005. Available online: https:/ / www.icomos.org/charters/xian-declaration.pdf (accessed on 8 September 2020).

13. Burra Charter. The Australia ICOMOS Charter for Places of Cultural Significance Australia ICOMOS Incorporated International Council on Monuments and Sites. 2013. Available online: https://australia.icomos.org/wp-content/uploads/The-Burra-Charte r-2013-Adopted-31.10.2013.pdf (accessed on 8 September 2020).

14. ICOMOS. The Declaration of San Antonio. 1996. Available online: https://www.icomos.org/en/resources/charters-and-texts/1 79-articles-en-francais / ressources / charters-and-standards/188-the-declaration-of-san-antonio (accessed on 8 September 2020).

15. Hennebo, D. Gartengeschichte-Gartendenkmalpflege. Versuch einer Bilanz. Das Gartenamt; Patzer Verlag: Hannover, Germany, 1985; pp. 168-182.

16. Sigel, B. Alles Erhaltene wird zum redenden Zeugnis. Das Gartendenkmal mit der Elle des Baudendenkmalpflegers gemessen. In Die Gartenkunst; Wernersche Verlags GmbH: Biblis Germany, 1993; pp. 273-282.

17. Majdecki, L. Ochrona i Konserwacja Zabytkowych Założeń Ogrodowych; Wydawnictwo Naukowe PWN: Warsaw, Poland, 1993.

18. Kovarik, I. Historische Gärten und Parkanlagen als Gegenstand eines Denkmal-orientirten Naturschutzes. In Naturschutz und Denkmalpflege; Kowarik, I., Schmidt, E., Sigel, B., Eds.; vdh Hochschulverlag an der ETH: Zürich, Switzerland, 1998. Available online: File:/ / /C:/Users/mj/Downloads/Sigeletal.1998WegezueinemDialogimGarten\%20(1).pdf (accessed on 10 January 2021).

19. De Jong, E.; Schmidt, E.; Sigel, B. . . s sie Hätten Nicht Unter einer Glasglocke Gestandenm Sondern im Lebendigen Strom der Geschichte Eine Einführung in das Thema. In Der Garten-Ein Ort des Wandels. Perpectiven für Die Denkmalpflege; De Jong, E., Schmidt, E., Sigel, B., Eds.; Hochschil-Verlag an der ETH: Zürich, Switzerlad, 2006.

20. Sikora, D. Specyfika Działań Konserwatorskich w Ogrodach Regularnych. Kur. Konserw. 2010, 7, 34-42. Available online: http://bazhum.muzhp.pl/media//files/Kurier_Konserwatorski/Kurier_Konserwatorski-r2010-t-n7/Kurier_Konserwat orski-r2010-t-n7-s32-42/Kurier_Konserwatorski-r2010-t-n7-s32-42.pdf (accessed on 10 January 2021).

21. Sikora, D. Konserwacja ogrodów regularnych; SGGW: Warsaw, Poland, 2011.

22. Hajós, G. Der historische Garten-Ein Ort des Wandels ode rein Ort der Erinnerungen? Die Gart. 2006, 2, 385-394.

23. Hajós, G. Rekonstruktion in der Gartendenkmalpflege, eine Problemstellung. In Rekonstruktion in der Gartendenkmalpflege; Hajos, G., Wolschke-Bulmahn, J., Eds.; Zentrum für Gartenkunst und Landschaftsarchitektur (CGL) Leibniz Universität Hannover: Hannover, Germany, 2007; pp. 18-26.

24. Hajós, G. Notes on the problem of authenticity in historical gardens and parks in the light of the Austrian experience. J. Gard. Hist. 2012, 15,67-83. Available online: https://www.researchgate.net/publication/254237272_Notes_on_the_problem_of_authe nticity_in_historic_gardens_and_parks_in_the_light_of_the_Austrian_experience (accessed on 20 February 2021). 
25. Rhotert, S. Fragen an die Gartendenkmalpflege. In Rekonstruktion in der Gartendenkmalpflege; Hajos, G., Ed.; Zentrum für Gartenkunst und Landschaftsarchitektur (CGL) Leibniz Universität Hannover: Hannover, Germany, 2007; pp. 60-62. Available online: https://www.cgl.uni-hanno-ver.de/fileadmin/cgl/Forschung/Publikationen/Broschueren/Broschu_re_Rekonstr uktion_in_der_Gartendenkmalpflege_.pdf (accessed on 12 January 2021).

26. Lowenthal, D. Passage du Temps dans le Paysage. Le Globe. Rev. Genev. Géographie 2009, 149, 177-179. Available online: https://www.persee.fr/doc/globe_0398-3412_2009_num_149_1_1564 (accessed on 20 February 2021).

27. Scheitzer, S. Möglichkeiten und Grenzen artefaktischen Wissens in dem Bild- und Textquellen einer Fragilen Gattung; Manuscript: Würzburg, Germany, 2011.

28. Schmidt, E. Erhaltung historischer Pflanzenbestände. Möglichkeiten und Grenzen. Die Grtenkunst 1997, 2, $270-273$.

29. Schmidt, E. Die Charta von Florenz nach dreissig Jahren kritisch betrachtet. In Denkmalpflege in Bremen; Das Landesamt für Denkmalpflege Bremen: Bremen, Germany, 2012; pp. 83-91.

30. Troll, H. Rekonstruktion in der Gartendenkmalpflege. Annäherungen. In Rekonstruktion in der Gartendenkmalpflege; Hajos, G., Ed.; Zentrum für Gartenkunst und Landschaftsarchitektur (CGL) Leibniz Universität Hannover: Hannover, Germany, 2007; pp. 60-62. Available online: https://www.cgl.uni-hanno-ver.de/fileadmin/cgl/Forschung/Publikationen/Broschueren/Broschu_re_ Rekonstruktion_in_der_Gartendenkmalpflege_.pdf (accessed on 18 January 2021).

31. Troll, H. Dtugi cień Karty Florenckiej-Ewolucja Standardów Konserwacji Zabytków Niemczech. Ochrona Zabytków; Narodowy Instytut Dziedzictwa: Warszawa, Poland, 2016; Volume 1, pp. 73-92. Available online: http://cejsh.icm.edu.pl/cejsh/element/bwmeta1 .element.desklight-fc8d27f3-c8cc-4b4d-988e-01a5ad2de541 (accessed on 12 January 2021).

32. Wimmer, C.A. Drei Hauptkomponenten in der Behandlung von historischen Gärten. In Rekonstruktion on der Gartendenkmal-pflege; Hajos, G., Ed.; Zentrum für Gartenkunst und Landschaftsarchitektur (CGL) Leibniz Universität Hannover: Hannover, Germany, 2007; pp. 38-40. Available online: https://www.cgl.uni-hanno-ver.de/fileadmin/cgl/Forschung/Publikationen/Broschueren/B roschu_re_Rekonstruktion_in_der_Gartendenkmalpflege_.pdf (accessed on 10 January 2021).

33. Gulliano, P.; Pomatto, E.; Gaino, W.; Devecchi, M.; Larcher, F. New Challenges for Historic Gardens' Restoration: A Holistic Approach for the Royal Park of Moncalieri Castle (Turin Metropolitan Area, Italy). Sustainability 2020, 12, 10067. [CrossRef]

34. Funsten, C.; Borsellino, V.; Schimmenti, E. A Systematic Literature Review of Historic Garden Management and Its Economic Aspects. Sustainability 2020, 12, 10679. [CrossRef]

35. Prigioniero, A.; Sciarrillo, R.; Spuria, L.; Zuzolo, D.; Marziano, M.; Scarano, P.; Tartaglia, M.; Guarino, C. Role of historic gardens in biodiversity-conservation strategy: The example of the Giardino Inglese of Reggia di Caserta (UNESCO) (Italy). Plant Biosyst. Int. J. Deal. All Asp. Plant Biol. 2020, 155, 1-11. Available online: https://www.tandfonline.com/doi/full/10.1080/11263504.2020 1810812 (accessed on 10 January 2021). [CrossRef]

36. Oishi, Y. Urban Heat Island Effects on Moss Gardens in Kyoto, Japan. Landsc. Ecol. Eng. 2019, 15, 177-184. Available online: https: / /link.springer.com/article/10.1007/s11355-018-0356-z (accessed on 10 December 2020). [CrossRef]

37. Counsell, J. An evolutionary Approach to Digital Recording and Information about Heritage Sites. In Proceedings of the 2001 Conference on Virtual Reality, Archeology, and Cultural Heritage-VAST'01, Glyfada, Greece, 28-30 November 2001; ACM Press: Glyfada, Greece, 2001; pp. 33-41, 362. Available online: https:/ /dl.acm.org/doi/10.1145/584993.584999 (accessed on 10 January 2021).

38. Zapłata, R. Autentyzm Zabytkowej Architektury i Palimpsest w Przestrzeni Historycznej-Nowe Media a Prezentacja Dziedzictwa Kulturowego. Architectus 2016, 1, 97-114. Available online: http://www.architectus.arch.pwr.wroc.pl/45/45_09.pdf (accessed on 12 January 2021).

39. Buchaniec, A.J. Autentyzm—Podstawowa Wartość w Konserwacji Zabytków Architektury. Ph.D. Thesis, Wydział Architektury Politechniki, Cracow, Poland, 1999. Available online: http:/ / fbc.pionier.net.pl/details/nntsbsn (accessed on 10 November 2020).

40. ICOMOS, Authenticity. A Bibliography. 2010. Available online: https://www.icomos.org/centre_documentation/bib/Biblio_aut henticity_2010.pdf (accessed on 10 January 2021).

41. Rouba, B.J. Autentyczność i Integralność Zabytków. Ochr. Zabyt. 2008, 4, 37-57. Available online: https://www.nid.pl/upload/ iblock/19c/19cf1f3005c3c71f2e0052ee43e22ffe.pdf (accessed on 18 January 2021).

42. Valéry, M.-F.; Toquin, A. Jardins du Moyen Âge; La Renaissance du Livre: Tournai, France, 2002.

43. European Landscape Convention, Florence. 20 December 2000. Available online: https://rm.coe.int/1680080621 (accessed on 12 January 2021).

44. Dutkiewicz, J.F. Sentymentalizm, Autentyzm, Automatyzm; Ochrona Zabytków Narodowy Instytut Dziedzictwa: Warszawa, Poland, 1961; pp. 3-16. Available online: http://yadda.icm.edu.pl/yadda/element/bwmeta1.element.desklight-b6b63f8c-ebf2-452c-9dfa -ed248eb20f57 (accessed on 12 January 2021).

45. Dezalier d'Argenville, A.-J. La Théorie et la Pratique du Jardinage; Paris 1709. Available online: https://gallica.bnf.fr/ark: /12148/btv1b8626274z/f7.image (accessed on 14 January 2021).

46. Swirida, I. W Poszukiwaniu Ukrytych Znaczeń. Park naturalny XVIII Stulecia a Wolnomularstwo. Ars Regia 1993, 2, 7-40.

47. Wegner, F. Der Freimaureregarten; Kulturförderverein Ruhrgebiet E.V. KFVR: Gladback, Germany, 2014.

48. Lichaczow, D. Poezja Ogrodów; Zakład Narodowy im. Ossolińskich: Wrocław, Poland; Warsaw, Poland; Kraków, Poland, 1991.

49. de Caus, S. Les Raisons des Forces Mouvantes; Paris 1615. Available online: https://library.si.edu/digital-library/book/raisonsd esforce00caus (accessed on 10 January 2021). 
50. Schickhart, H. Beschreibung einer Reiß, welche ... Friderich Hertzog zu Würtemberg vnnd Teck, ... im Jahr 1599 selb neundt, auß dem Landt zu Würtemberg, in Italiam Gethan; Mömpelgard, 1602. Available online: https://reader.digitale-sammlungen.d e/de/fs1/object/display/bsb11212296_00005.html (accessed on 10 January 2021).

51. Ramelli, A. Le Diverse et Artificiose Machine del Capitano Agostino Ramelli; Firenze 1588. Available online: https:// digital.scie ncehistory.org/works/4b29b614k (accessed on 12 January 2021).

52. Böckler, G.A. Architectura Curiosa Nova; Nürnberg ca 1664. Available online: https://blogs.ethz.ch/digital-collections/2012/0 8/17/georg-andreas-bockler-architectura-curiosa-nova-nurnberg-1664/ (accessed on 18 January 2021).

53. Smit, T. The Lost Gardens of Heligan; Orion Publishing: London, UK, 2000.

54. Thoday, P. Science and Craft in Understanding Historic Gardens and Their Management. In Gardens $\mathcal{E}$ L in Historic Building Conservation; Harney, M., Ed.; John Wiley \& Sons, LTD.: Oxford, UK, 2014; pp. 141-148.

55. Myczkowski, Z.; Wowczak, J. Kreacja konserwatorska na przykładzie ogrodów wilanowskich. Aura 2010, 9, 10-14.

56. Ciołek, G.; Chrabelski, K. Uwagi o Potrzebie i Metodzie Odbudowy Zabytkowych Ogrodów. Ochrona Zabytków 1949, 1, 15-18. Available online: http:/ / yadda.icm.edu.pl/yadda/element/bwmeta1.element.desklight-538a588b-75ed-4682-b19f-a46dbc2eadc0 (accessed on 10 January 2021).

57. Landsberg, L. The Medieval Garden; University of Toronto Press: Toronto, ON, Canada, 2003.

58. Jellicoe, G.; Jellicoe, S.; Goode, P.; Lancaster, M. The Oxford Companion to Gardens; Oxford University Press: Oxford, NY, USA, 2001; pp. 96-112.

59. Piwocki, K. Zabytek rezerwat, park kultury: Muzeum w plenerze. Ochr. Zabyt. 1961, 14, 54-55.

60. Zachwatowicz, J. Ochrona Zabytków w Polsce; Polonia: Warsaw, Poland, 1965.

61. Kowalski, K. Od zabytku do dyskursu. O kilku Źródłach Współczesnej Definicji Dziedzictwa. Zeszyty Naukowe Uniwersytetu Jagiellońskiego. Pr. Etnogr. 2017, 45, 1-14. Available online: https://www.ejournals.eu/Prace-Etnograficzne/2017/45-1-2017/art /10504/ (accessed on 15 January 2021).

62. van Buren, A.H. Reality and Literary Romance in the Parc of Hesdin. In Medieval Gardens; Macdougall, E.B., Ed.; Dumbarton Oaks: Washington, WA, USA, 1983; pp. 115-134.

63. De' Crescenzi, P. Ruralia commode; (manuscript) 1304. Ruralium Commodorum Libri Duodecima; Schüssler, Augsburg 1471. 1st edition.

64. Mollet, C. Théâtre des plans et jardinages; Paris 1652. Available online: https://gallica.bnf.fr/ark:/12148/bpt6k1042641w.image (accessed on 10 January 2018).

65. Estienne, C. Praedium rusticum [ ... ]; Lutetia 1554. Available online: https://gallica.bnf.fr/ark:/12148/btv1b8608310f (accessed on 10 February 2018).

66. Lauremberg, P. Horticultura; Francofurti ad Moenum 1631. Available online: http:/ /diglib.hab.de/wdb.php?dir=drucke/6-4-o ec-1 (accessed on 10 February 2018).

67. Hesse, H. Neue Garten-Lust; Leipzig 1696. Available online: https://wellcomecollection.org/works/umwxfdfj/items?canvas=1 \&langCode=ger\&sierraId=b30513285 (accessed on 22 January 2021).

68. Camerarius, J. Camerarius Flirilegium, ca 1589, Complete Facsimile ed.; Harald Fischer Verlag: Erlangen, Germany, 2004.

69. Jagiełło, M. Ogród Caspara Wilhelma Scultetusa (Scholza) na Przedmieściu Świdnickim we Wrocławiu i Jego Powiązania Artystyczne. In Nie Tylko Zamki; Chorowska, M., Ed.; Oficyna Wydawnicza Politechniki Wrocławskiej: Wrocław, Poland, 2005; pp. 471-482.

70. Volkamer, J.C. Nürnbergische Hesperides; Nürnberg 1708. Available online: http://digital.bibliothek.uni-halle.de/hd/content/p ageview / 242577 (accessed on 10 September 2020).

71. Brzezowski, W. The Silesians and Theories of Garden Art from the 16th to the 18th Century with New Research from the Wrocław University Library collection. Architectus 2013, 1,3-10. Available online: http://architectus.pwr.edu.pl/online_33_01en.html (accessed on 10 September 2020).

72. Zemplin, A. Salzbrunn und Seine Mineralquellen. Im Anhange: Fürstenstein in der Gegenwart und Vergangenheit, Breslau 1822. Available online: https:/ / books.google.pl/books?id=tnJeAAAAcAAJ\&printsec=frontcover\&hl=pl\#v=onepage\&q\&f=false (accessed on 10 September 2020).

73. Addison, J. Remarks on Several Parts of Italy etc. in The Years 1701, 1702, 1703, London 1745. Available online: https: / / quod.lib.umich.edu/e/ecco/004846589.0001.000?view=toc (accessed on 10 January 2021).

74. Kościerza, I. Sublime (w) Historii. Wzniosłość Jako Narzędzie i Przedmiot Badań. Pamięć Spraw. 2012, 11, 115-137. Available online: http: / cejsh.icm.edu.pl/cejsh/element/bwmeta1.element.desklight-7b96b0f2-399e-43fb-92a1-b2c2fa739a27 (accessed on 10 January 2021).

75. Merian, M. Theatrum Europaeum; Bd. 1-21, Franckfurt 1633-1738. Available online: https://en.wikipedia.org/wiki/Theatrum _Europaeum (accessed on 11 December 2020).

76. Merian, M.; Zeiler, M. Topographia Germaniae; Bd. 1-38, (1642-1660s). Available online: https://en.wikipedia.org/wiki/Topogr aphia_Germaniae (accessed on 10 January 2021).

77. Vischer, G.M. Topographia Archiducatus Austriae Superiors Modernae, Augsburg 1674. Available online: https://fedora.phaid ra.univie.ac.at/fedora/objects/o:25730/methods/bdef:Book/view (accessed on 10 January 2021).

78. Vischer, G.M. Topographia Ducatus Styriae; AGRIS: Graz, Austria, 1681. 
79. Wening, M. Historico-Topographica Descriptio; Bd. 1-4, München 1701-1726. Available online: https://bildsuche.digitale-samml ungen.de/index.html?c=viewer\&bandnummer=bsb00063022\&pimage=00001\&v=100\&nav=\&l=de (accessed on 12 January 2021).

80. Dahlberg, E. Suecia Antiqua et Hodierna; Holmiae 1698-1720. Available online: https://suecia.kb.se/F/?func=find-b\&local_ba se=sah (accessed on 15 January 2021).

81. Puffendorf von, S. De Rebus a Carolo Gustavo Sveciae Rege Gestis; Norymb 1696. Available online: https://polona.pl/item/sam uelis-liberi-baronis-de-pufendorf-de-rebus-a-carolo-gustavo-sveciae-rege-gestis,NzkyMzU3NQ/3/\#info:metadata (accessed on 20 January 2021).

82. Werner, F.B. Topographia Silesiae; Geheims Staatsarchiv Preussischer Kulturbesitz Berlin-Dahlem: Berlin, Germany, 2018; Volume 1-5.

83. Werner, F.B. Topographia oder Prodromus Delineati Silesiae Ducatus [ . . . ], t.1 (Manuscript), ca 1750. Biblioteka Uniwersytecka Wrocław, Odział Rękopisów, sygn.R550. Available online: https://www.bibliotekacyfrowa.pl/dlibra/publication/7114/edition /14302/ content (accessed on 20 January 2021).

84. Kleiner, S. Vera et Accurata Delineatio Omnium Templorum et Coenobiorum quae Tam in Caesarea Urbe ac Sede Vienna, Austriae; part 1-4; Augsburg 1724-1737. Available online: https:/ / www.e-rara.ch/zut/content/zoom/201865 (accessed on 22 January 2021).

85. Falda, G.-B. Ville e Giardini di Roma; Roma. Available online: https://archive.org/stream/gri_33125008634194\#page/n5/mode /2up (accessed on 10 January 2021).

86. Rossi, G.G. Li Giardini di Roma; Roma 1683. Available online: https:/ / polona.pl/item/li-giardini-di-roma-con-le-loro-piante-al zate-e-vedute-in-prospettiva,NTg1MTk5MQ/16/\#info:metadata (accessed on 10 January 2021).

87. Diesel, M. Erlustierende Augenweide in Vorstellung herrlicher Gärten und Lustgebäude; Augsburg 1717. Available online: https: / / bildsuche.digitale-sammlungen.de/index.html?c=viewer\&bandnummer=bsb00073534\&pimage=7\&v=2p\&nav=\&l=de $(\mathrm{ac}-$ cessed on 10 January 2021).

88. Blondel, J.-F. De la Distribution des Maisons de Plaisance et de la Décoration des Edifices en Général; Charles-Antoine Jombert: Paris, France, 1737; Volume 1-2, pp. 1737-1738. Available online: https://gallica.bnf.fr/ark:/12148/btv1b8624593q.image (accessed on 20 January 2021).

89. Le Rouge, G.-L. Jardins Anglo-Chinois à la Mode; Cahiers 1-21, Paris 1775-1789. Available online: https:/ /gallica.bnf.fr/html/ und/images/les-jardins-anglo-chinois-de-georges-louis-lerouge?mode=desktop (accessed on 20 January 2021).

90. Czartoryska, I. Myśli Różne o Zakładaniu Ogrodów; Wrocław 1805. Available online: https://polona.pl/item/mysli-rozne-o-s posobie-zakladania-ogrodow,MTIzMzk2OQ/2/\#info:metadata (accessed on 20 January 2021).

91. Hirschfeld, C.C.L. Theorie der Gartenkunst; Bd. 1-5, Leipzig 1779-1785. Available online: https://digi.ub.uni-heidelberg.de/di glit/hirschfeld1779 (accessed on 20 January 2021).

92. de Caus, S. Hortus Palatinus: A Friderico Rege Boemiae Electore Palatino Heidelbergae Exstructu; Frankfurt a. M., 1620. Available online: https: / / gallica.bnf.fr/ark:/12148/bpt6k15122355.image (accessed on 10 January 2021).

93. von Pückler-Muskau, H. Andeutungen über Landschaftsgärtnerei, Verbunden mit der Beschreibung Ihrer Praktischen An-wendung in Muskau; Stuttgart, 1834. Available online: https:/ / digi.ub.uni-heidelberg.de/diglit/pueckler1834a (accessed on 20 January 2021).

94. Żaba, A. Drawing of F.B. Werner and geometry. J. Pol. Soc. Geom. Eng. Graph. 2016, 28, 63-70. Available online: http://yadda.icm. edu.pl/yadda/element/bwmeta1.element.baztech-c63e043f-ed01-4b50-b416-b1bfab6d4fec (accessed on 10 January 2021).

95. Sroczyńska, K. Zygmunt Vogel, Rysownik Gabinetowy Stanisława Augusta, Zakład Narodowy im; Ossolińskich: Wrocław-WarsawKraków, Poland, 1969.

96. MAPIRE-Historical Maps Online. Available online: http:/ / mapire.eu (accessed on 20 January 2021).

97. Zachariasz, A. Przydatność Archiwalnych Źródeł Kartograficznych dla Współczesnych Badań Krajobrazowych. Prace Komisji Krajobrazu Kulturowego. Pol. Tow. Geogr. 2012, 16, 63-83. Available online: http://krajobraz.kulturowy.us.edu.pl/publikacje.art ykuly/16.kartografia/4-zachariasz.pdf (accessed on 5 January 2021).

98. Pozzana, M. Giardini Storici. Principi e Techniche della Conservation; Alinea Città: Florence, Italy, 1996.

99. Mosser, M. The Impossible Quest of the Past. In The Architecture of Western Gardens; Mosser, M., Teyssot, G., Eds.; MIT Press: Cambridge, UK, 1991; pp. 525-529.

100. Bronwyn, H. Innovation in Conservation, a Timeline History of Australia ICOMOS and the Burra Charter; Sydney 2015. Available online: https:/ /www.researchgate.net/publication/316924146_Innovation_in_Conservation_a_Timeline_History_of_Australi a_ICOMOS_and_the_Burra_Charter (accessed on 22 January 2021).

101. Heinich, N. La Fabrique du Patrimoine. De la Cathédrale à la Petite Cuillère; Éditions de la Maison des Sciences de L’Homme: Paris, France, 2009.

102. Obad Šćitaroci, M.; Marić, M.; Vahtar-Jurković, K.; Knežević, K.R. Revitalisation of Historic Gardens-Sustainable Models of Renewal. In Cultural Urban Heritage. Urban Book Series; Springer: Cham, Switzerland, 2019; pp. 423-441.

103. Cabral, I.; Keim, J.; Engelmann, R.; Kraemer, R.; Siebert, J.; Bonn, A. Ecosystem services of allotment and community gardens: A Leipzig, Germany case study. Urban For. Urban Green. 2017, 23, 44-53. Available online: http:/ /dx.doi.org/10.1016/j.ufug.2017.0 2.008 (accessed on 10 January 2021). [CrossRef]

104. ICOMOS International “Journeys to Authenticity" Initiative. Available online: http://www.icomos.pt/index.php/2-inicial/160icomos-international-journeys-to-authenticity-initiative (accessed on 8 September 2020).

105. Report on the Scientific Council meeting in Marrakesh-14 October 2019. Available online: https://www.icomos.org/en/abouticomos / governance/general-information-about-the-general-assembly / list-of-general-assemblies/annual-general-assembly2019/69712-report-on-the-2019-scientic-council-meeting-in-marrakesh-october-2019 (accessed on 10 January 2021). 